\title{
Glacial dynamics in pre-Alpine narrow valleys during the Last Glacial Maximum inferred by lowland fluvial records (northeast ltaly)
}

\author{
Sandro Rossato ${ }^{1}$, Anna Carraro ${ }^{2}$, Giovanni Monegato ${ }^{2}$, Paolo Mozzi ${ }^{1}$, and Fabio Tateo ${ }^{2}$ \\ ${ }^{1}$ Department of Geosciences, University of Padova, Padova, 35131, Italy \\ ${ }^{2}$ Institute of Geosciences and Earth Resources (IGG) - National Research Council (CNR), Padova, 35131, Italy
}

Correspondence: Sandro Rossato (sandro.rossato@unipd.it)

Received: 7 March 2018 - Discussion started: 14 May 2018

Revised: 24 July 2018 - Accepted: 3 September 2018 - Published: 26 September 2018

\begin{abstract}
During the Last Glacial Maximum (LGM), most of the major glaciated basins of the European Southern Alps had piedmont lobes with large outwash plains; only a few glaciers remained within the valley. Piedmont glaciers have left well-preserved terminal moraines, which allow for investigations to be carried out and inferences to be made regarding their evolution and chronology. Valley glaciers' remnants, on the contrary, are often scantly preserved, and changes can only be detected through correlations with glaciofluvial deposits in downstream alluvial basins. The Brenta glacial system's dynamics in the glacier's terminal tract have been inferred through a wide range of sediment analysis techniques on an alluvial stratigraphic record of the Brenta megafan (northeast Italy), and via the mapping of in-valley glacial/glaciofluvial remnants. Glaciers flowing across narrow gorges could possibly be slowed/blocked by such morphology, and glacial/sediment fluxes may then be diverted to lateral valleys. Moreover, narrow valleys may induce glaciers to bulge and form icefalls at their front, preventing the formation of terminal moraines. The Brenta Glacier was probably slowed/blocked by the narrow Valsugana Gorge downstream of Primolano and was effectively diverted eastwards across a wind gap (Canal La Menor Valley), joining the Cismon/Piave glaciers near Rocca and ending $\sim 2 \mathrm{~km}$ downstream. The Cismon and Piave catchments started to contribute to the Brenta system just after $27 \mathrm{ka}$ cal BP until at least $\sim 19.5 \mathrm{ka}$ cal BP. After the glaciers collapsed, the Piave River once again flowed into its main valley, whilst the Cismon continued to merge with the Brenta.

This investigation shows that glacial catchments may vary significantly over time during a single glaciation in rugged Alpine terrains. Sand petrography and the chemical/mineralogical composition of sediments are powerful proxies for tracing such variations, as they propagate through the glacial and glaciofluvial systems and can be recognized in the alluvial stratigraphic record far downstream from the glacier front.
\end{abstract}

\section{Introduction}

Mountain glaciers are complex systems, and the evolution of these systems affects both their mountain basins and the alluvial plains that receive the glaciofluvial water and sediment flux (e.g. Russell et al., 2006). Few minor valley glaciers are currently present in the highest areas of the European Alps (Evans, 2006), whereas during Pleistocene glaciations large ice streams flowed along most of the Alpine valleys, leading to deep landscape modifications (e.g. Koppes and Montgomery, 2009; Preusser et al., 2010; Wirsig et al., 2016). Most of the major glaciated basins had piedmont lobes with large outwash plains, where stratigraphic reconstruction and available chronology has allowed researchers to infer the evolution of the glacial system (Monegato et al., 2007; Preusser et al., 2011; Ravazzi et al., 2012; Fontana et al., 2014). However, there are catchments where glaciers remained within the valley, and their evolution could only be detected through correlations with the related glacioflu- 
vial deposition in the piedmont area (van Husen and Reitner, 2011; Rossato et al., 2013).

The Last Glacial Maximum (LGM) was the last cold extreme on Earth, and it provided the most well-preserved sedimentary and geomorphic record among all Pleistocene glaciations (Bowen, 2009; Clark et al., 2009; Hughes and Gibbard, 2015). In Europe, the Alps and their foreland constitute a key region for LGM studies, as evidence of this event is widespread and chronologically well framed between 30 and $17.5 \mathrm{kacal}$ BP (e.g. Ivy-Ochs et al., 2008; Ivy-Ochs, 2015; Rossato and Mozzi, 2016; Monegato et al., 2017). Moreover, the Alps constitute an effective barrier for wind circulation (Florineth and Schlüchter, 2000; Luetscher et al., 2015) and offer the unique opportunity to validate climate models (e.g. Smiatek et al., 2009; Torma et al., 2015) and study how glacial processes affect mountain chains (e.g. Norton et al., 2010). LGM glaciers filled the valleys fed by the major accumulation zones located in the axial and highest part of the Alps (e.g. van Husen, 1987; Kelly et al., 2004; Wirsig et al., 2016). In the southern Alpine sector, topography greatly influenced glacier evolution (Wirsig et al., 2016) due to different wind circulation regimes (Luetscher et al., 2015). Alpine glaciers and their sedimentary outputs proved to react differently to climatic signals, in both the northsouth (e.g. Luetscher et al., 2015) and west-east directions (Becker et al., 2016; Monegato et al., 2017; Seguinot et al., 2017). Differences are also found when dealing with neighbouring glacial systems, due to their size, catchment topography and possible glaciers confluences and transfluences (e.g. Kelly et al., 2004; Monegato et al., 2007; Rossato et al., 2013).

The present availability of a wide range of proxies, coupled with the increased accuracy of geochronological methods (Brauer et al., 2014), allows for a better assessment of glaciers' behaviour during the LGM compared to earlier studies undertaken in the Alps, which were mostly based on landform and deposit characterization (e.g. Penck and Brückner, 1909; Sacco, 1937; Venzo et al., 1977; Schlüchter, 1986; van Husen, 1987). Furthermore, the analysis of loess and palaeosols has been coupled with biological proxies, such as pollen, chironomids, charcoal and many more (e.g. Heiri et al., 2014; Samartin et al., 2016). Petrographic/mineralogical studies of sediments have also supported palaeoenvironmental reconstructions and allowed researchers to infer variations in the sedimentary systems (Garzanti et al., 2011).

In this paper we investigate the interaction between the LGM glaciers in the middle Brenta Valley (also known as "Valsugana", in the Italian Fore-Alps) and the related glaciofluvial system in the piedmont plain (Fig. 1). During the LGM, the Brenta glacial system received contributions from the major Adige (Etsch) Glacier (Trevisan, 1939; Tessari, 1973; Avanzini et al., 2010; Rossato et al., 2013); the Brenta system also fed a fluvial megafan, which is one of the most prominent sedimentary alluvial systems on the southern side of the Alpine chain (Mozzi, 2005; Fontana et al., 2014).
The main aim of this paper is to explore and define the possibility of correlating glacial advances and transfluences in mountain areas with sedimentation pulses in the lowlands using integrated geomorphic, sedimentary, petrographic, mineralogical, geochemical and geochronological evidence.

\section{Study site}

The Venetian Fore-Alps are geologically detached from the Dolomites by the Valsugana fault (Castellarin et al., 2006), and are characterized by a belt of carbonate plateaus deeply carved by the lower reaches of the Astico, Brenta, Cismon and Piave valleys (Fig. 1). Except for the Astico River, which has a catchment that is restricted to the western part of the Venetian Fore-Alps, the other rivers have their upper catchments in the Dolomites. The Dolomites region includes the Permo-Triassic sedimentary successions (sandstones, dolostones, limestones and volcanic rocks), the low-grade metamorphic basement and the Permian porphyries (e.g. Bartolomei et al., 1969; Avanzini et al., 2010; Fig. 1). The Brenta and Cismon catchments also include the Permian plutonic rocks of Cima d'Asta (Fig. 1). In the footwall of the Valsugana fault the Jurassic-Tertiary sedimentary succession crops out, including different types of limestones, turbiditic sequences and the terrigenous units of the Southalpine foredeep (e.g. Massari et al., 1986; Barbieri and Grandesso, 2007; Stefani et al., 2007). In particular, in the Cismon catchment, all around Lamon (Fig. 1), micritic limestones crop out extensively (Tessari, 1973). Here, a remarkable fluvial aggradation took place during/after deglaciation, later followed by river incision and the formation of a terrace staircase. The highest and largest of these terraces is located about $600 \mathrm{~m}$ a.s.l., $200 \mathrm{~m}$ above the Cismon Valley bottom. The deposition of such a large amount of sediment was probably due to the damming of the Cismon Valley south of Lamon, which possibly occurred due to a large dead-ice mass or a landslide event, although no direct evidence of this has been found (Tessari, 1973).

The plateaus characterizing the Venetian Fore-Alps (Castiglioni et al., 1988) have mean elevations ranging from 900 to $2000 \mathrm{~m}$ a.s.l. and hosted small cirque or plateau glaciers during the last glaciation (Trevisan, 1939; Carraro and Sauro, 1979; Baratto et al., 2003; Barbieri and Grandesso, 2007). The major Astico (Cucato, 2001; Rossato et al., 2013) and Piave (Venzo, 1977; Carton et al., 2009) valleys were carved by ice streams that extended to the lower valley reaches and left well-preserved terminal moraines (Fig. 1). Despite the large megafan ascribed to the LGM (Mozzi, 2005; Fontana et al., 2008; Rossato and Mozzi, 2016), the Brenta Glacier is the only major system in the southeastern Alps that left no clear evidence of terminal moraines (Castiglioni, 2004). The reason that the Brenta system did not follow this evolutionary path remains unresolved, although some early authors have already broached this challenging topic (e.g. 


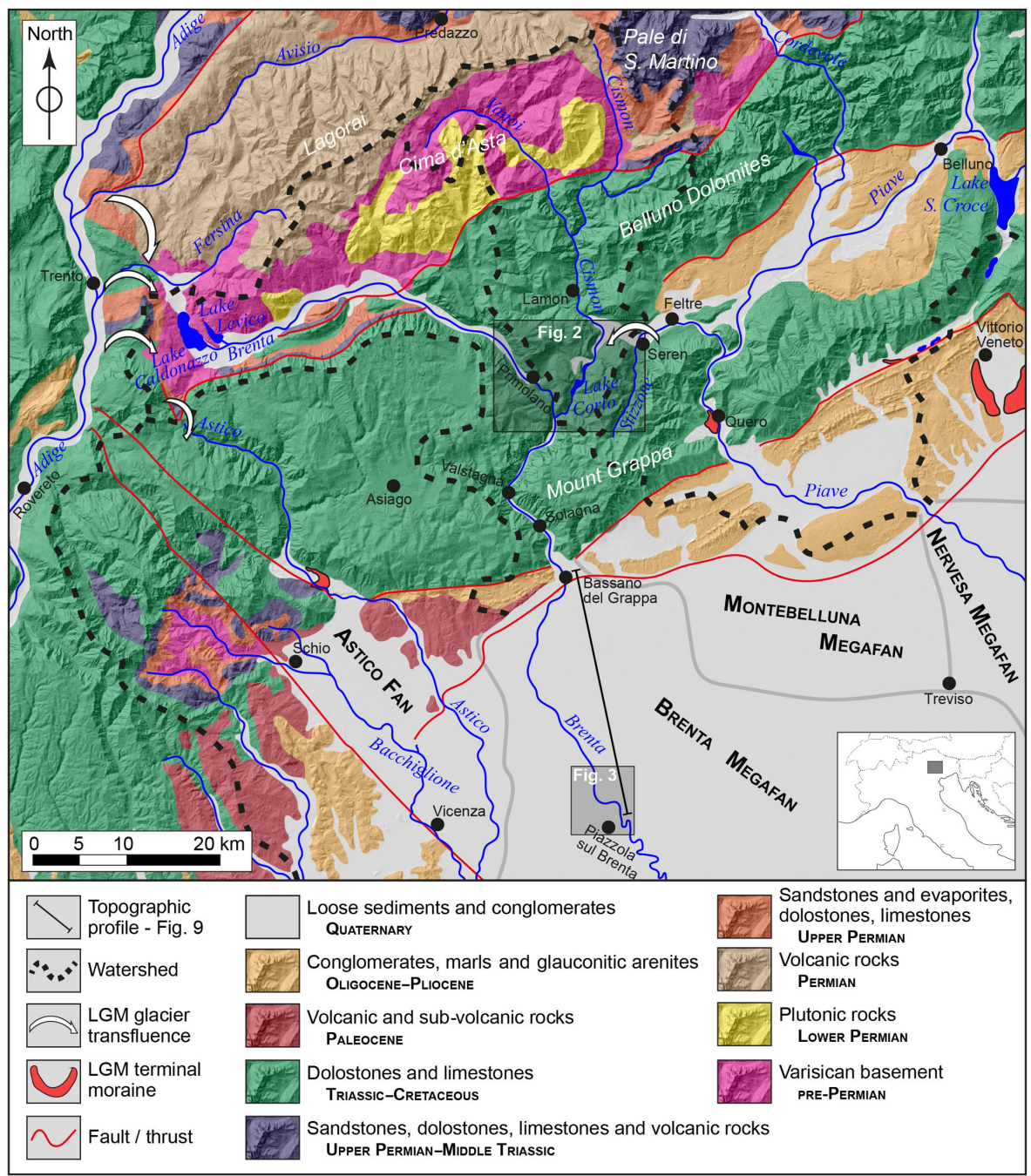

Figure 1. A geological sketch of the study area. The map is based on the "Structural model of Italy" (Bigi et al., 1990) and local geological maps (Bartolomei et al., 1969; Dal Piaz et al., 1946; Barbieri and Grandesso, 2007; Avanzini et al., 2010). It also overlies a Shuttle Radar Topography Mission (SRTM) derived digital elevation model (DTM; $30 \mathrm{~m}$ cell size) (source: http://viewfinderpanoramas.org/, last access: 12 April 2018).

Taramelli, 1882; Penck and Brückner, 1909; Castiglioni, 1940). Taramelli (1882) and Castiglioni (1940) placed the Brenta Glacier front near the town of Valstagna, about $10.5 \mathrm{~km}$ south of the confluence between the Brenta and Cismon valleys (Fig. 1), while Penck and Brückner (1909) located it about $6 \mathrm{~km}$ further to the south, near the town of Solagna. Due to the lack of direct geomorphic or sedimentary evidence of the glacier's front, both interpretations were based on speculation that the glacier gradually thinned downstream of the last preserved lateral moraine at Enego (elevation 760-790 m a.s.1.). The terminal tract of the Cismon Valley, called Corlo Valley, was closed by a dam in 1953 and filled by the artificial Corlo Lake (Fig. 1), so no further survey is presently possible.
The Brenta fluvial megafan is part of the foreland basin of the uplifting eastern Southalpine chain (e.g. Castellarin et al., 2006; Stefani et al., 2007). This megafan extends from the Brenta Valley mouth to the present Venetian coastline. It can be roughly separated into two sectors: (i) piedmont ( $\sim 20 \mathrm{~km}$ from the apex), made of gravel and with an average topographic gradient of 3-5 and (ii) low plain, made of sandy fluvial ridges and silty-clayey floodplain, with a topographic gradient that decreases to less than 1\%o (Mozzi, 2005; Mozzi et al., 2013; Fontana et al., 2008).

\section{Methods}

This investigation was carried out via a field survey, coring, petrographic and mineralogical analyses, and remote sens- 
Table 1. Conventional, calibrated and median probability ${ }^{14} \mathrm{C}$ ages obtained from samples collected from RB1 and PM1 cores. The calibration was carried out with OxCal (version 4.2, Ramsey, 2009), based on the IntCal13 calibration curve (Reimer et al., 2013).

\begin{tabular}{|c|c|c|c|c|c|c|c|c|c|}
\hline \multirow[b]{2}{*}{$\begin{array}{l}\text { Sample } \\
\text { name }\end{array}$} & \multirow[b]{2}{*}{$\begin{array}{l}\text { Lab. } \\
\text { code }\end{array}$} & \multirow[b]{2}{*}{ Material } & \multirow[b]{2}{*}{$\begin{array}{r}\text { Depth } \\
{[\mathrm{m}]}\end{array}$} & \multirow[b]{2}{*}{$\begin{array}{r}\text { Thickness } \\
{[\mathrm{cm}]}\end{array}$} & \multicolumn{2}{|c|}{$\begin{array}{l}\text { Uncalibrated age } \\
\text { [years BP] }\end{array}$} & \multicolumn{3}{|c|}{$\begin{array}{c}\text { Calibrated age } \\
(\text { IntCal13 }-2 \sigma) \text { [years BP] }\end{array}$} \\
\hline & & & & & $\begin{array}{l}\text { Lab. } \\
\text { age }\end{array}$ & $\begin{array}{r}\text { Uncertainty } \\
( \pm)\end{array}$ & Min & Max & $\begin{array}{r}\text { Median } \\
\text { prob. }\end{array}$ \\
\hline PM1-1 & UZ-6073 & Peat & 9.00 & 1.5 & 16700 & 60 & 19945 & 20362 & 20147 \\
\hline PM1-2 & UZ-6074 & Peat & 13.45 & 1 & 19500 & 75 & 23167 & 23754 & 23495 \\
\hline RB1-1 & UZ-6075 & Peat & 9.30 & 1.5 & 19050 & 70 & 22648 & 23221 & 22938 \\
\hline RB1-2 & UZ-6076 & Peat & 21.80 & 1 & 21610 & 90 & 25715 & 26058 & 25888 \\
\hline RB1-3 & UZ-6077 & Peat & 27.50 & 1 & 22660 & 90 & 26634 & 27296 & 27013 \\
\hline
\end{tabular}

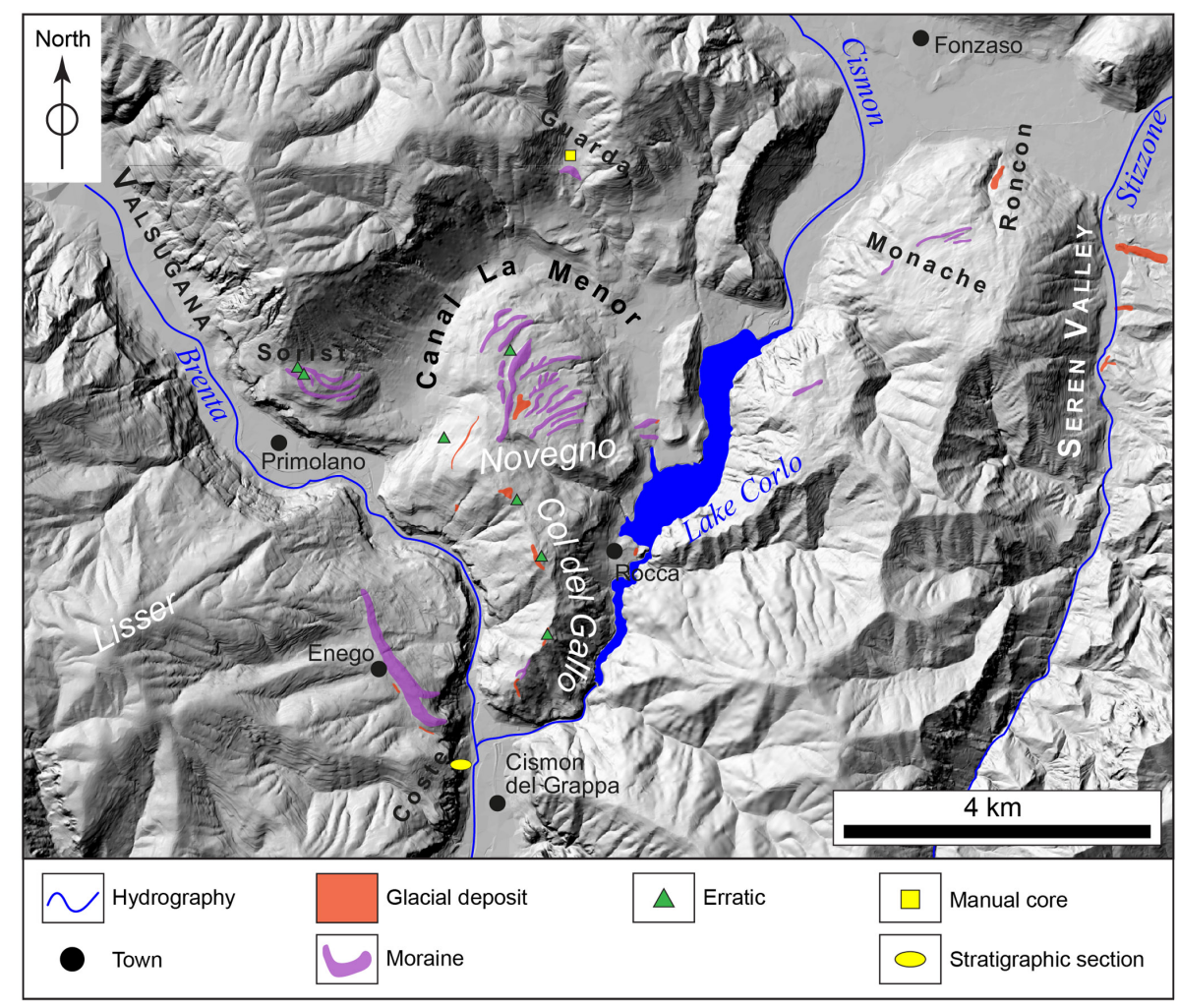

Figure 2. Outcrops map of the middle Valsugana sector derived from field surveys and remote sensing data. Polygons/symbols overlie a $5 \mathrm{~m}$ cell DTM (modified from data distributed by Regione Veneto; source: http://idt.regione.veneto.it/app/metacatalog/, last access: 13 April 2018).

ing. All methods and results are presented independently, whilst their meaning, implications and interconnections are discussed thereafter.

\subsection{Field survey}

Extensive mapping of the Quaternary sediments cropping out in the middle Valsugana and at the junctions with the Canal La Menor and lower Cismon (Corlo) valleys, was performed (Fig. 2). Sedimentary facies were observed and described in the outcrops to identify their original depositional setting; particular attention was devoted to the lithology of the clasts, which provided information on the provenance of the sediments. In this perspective, the geology of the eastern South Alps (Fig. 1) allowed for a clear distinction of each drainage basin with different petrographic signatures. Porphyries, granites and metamorphic rocks (i.e. Permian volcanic rocks, Lower Permian plutonic rocks and pre-Permian Varisican basement in Fig. 1, respectively) are indicators of the Brenta and Cismon valleys and, thanks to their high resis- 
tance to weathering, can help identify glacial deposits upon a carbonate bedrock.

Relevant landforms were accurately surveyed, with particular attention being paid to the LGM moraines, which are generally well preserved and quite easily identifiable in these areas (as little anthropogenic activity has taken place).

\subsection{Cores}

Two $30 \mathrm{~m}$-long cores were drilled near the city of Piazzola sul Brenta, in the upper part of the Brenta megafan. The cores were drilled about $5 \mathrm{~km}$ apart, at a topographic elevation of approximately $30 \mathrm{~m}$ a.s.1. (Fig. 3) and were part of a pilot study on groundwater geochemistry (Carraro et al., 2013, 2015). They were described based on the lithofacies of the sediments and sampled for sand petrography and mineralogical analyses. Five organic samples were collected from the inner part of the cores to minimize contamination and were dated using the ${ }^{14} \mathrm{C}$ AMS method at the radiocarbon laboratory of the University of Zurich (Switzerland) (Table 1). OxCal software (version 4.2, Bronk Ramsey, 2009; IntCal13 calibration curve, Reimer et al., 2013) was used to calibrate laboratory ages.

A single hand core was drilled in the Guarda area, on the northern flank of the Canal La Menor Valley, uphill from an elongated ridge that has been identified as a LGM lateral moraine (see Section 4 and Fig. 2 for location), at about $660 \mathrm{~m}$ a.s.1. This borehole was drilled with a hand auger (Edelman combination type, Ejikelkamp $^{\mathrm{TM}}$ ), which allowed for a semi-disturbed sequence of fine sediments to be obtained (with the limitation that the maximum grain size of the sediments that can be sampled is coarse sand to fine gravel).

\subsection{Sand petrography}

Ten samples were collected from the two long cores for provenance analysis. The entire sand fraction was isolated and impregnated in an epoxy resin according the methodology from Gazzi et al. (1973), in order to obtain samples for thin-section analysis comparable with river endmembers as per Garzanti et al. (2006) and Monegato et al. (2010). These samples were subsequently stained with Alizarin Red solution for the determination of the carbonate phases. Following the Gazzi-Dickinson method, 400 points per thin section were counted using a $0.5 \mathrm{~mm}$ grid spacing (Ingersoll et al., 1984). Data and parameters are reported in Table 2 and plotted in ternary diagrams.

Principal component analysis (PCA) was performed using CoDaPack (Comas and Henestrosa, 2011), and a compositional biplot (Aitchinson and Greenacre, 2002) was utilized to better visualize the dataset and the variables. The ternary diagrams with the most representative variables are presented in order to discuss the data structure. Centring (e.g. Buccianti et al., 1999; von Eynatten et al., 2002) was used to avoiding disturbances related to the dominance of one or two compo-

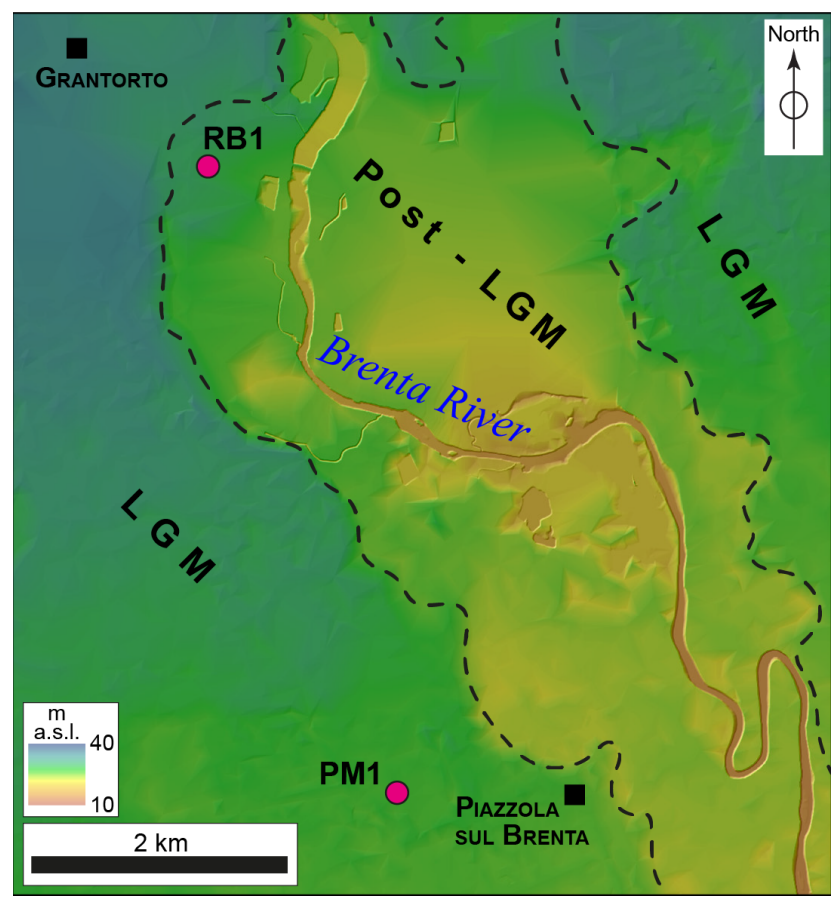

Figure 3. Location of the PM1 and RB1 cores (purple circles). The background is a $5 \mathrm{~m}$ cell DTM (modified from data provided by Regione Veneto, 2011), stretched to highlight elevation changes. Scarps bounding the post-glacial incision of the Brenta megafan are denoted by black dashed lines.

nents. In the statistical analysis, petrofacies of modern rivers (Garzanti et al., 2006; Monegato et al., 2010) were included for comparison in order to assess the sediment provenance in the different stratigraphic intervals.

In addition, the statistical technique from Vezzoli and Garzanti (2009) was also adopted to assess the contribution of the major drainage systems of the area related to the Brenta, Cismon and Piave rivers (Fig. 1) as endmembers. The parameters were then compared to evaluate possible matches between these catchments, and results with $R^{2}>0.7$ were considered robust. Except for one sample (RB1-8), all the samples show a good interpretation confidence (Table 2).

\subsection{X-ray diffraction (XRD)}

In order to minimize preferred orientation, samples were pulverized and backloaded. A Philips X'Pert Pro diffractometer $(\mathrm{Cu}$ tube and secondary monochromator) was utilized. The mineral constituents were quantified using HighScore plus software following Rietveld refinement (Young, 1993); zincite ( $\mathrm{ZnO}$ ) was added as an internal standard (sample $:$ standard $=10: 1$ weight ratio). Rietveld refinement also allowed for the estimation of the amorphous components (labelled Am.XRD, in Table S1).

To check the reliability of the mineral quantification, the chemical composition of samples was calculated us- 
Table 2. Detrital modes of the sand fraction collected on RB1 and PM1 cores. List of acronyms: Q represents quartz; F represents feldspars; Lvf represents felsic volcanic and sub-volcanic lithic fragments; Lvi represents intermediate and mafic lithic fragments; Lvp represents plutonic lithic fragments; Lcc represents limestone grains; Lcd represents dolostone grains; Lp represents shale and siltstone lithic fragments; Lch represents chert grains; Lms represents low-grade metamorphic lithic fragments; and Lmi represents medium-grade metamorphic lithic fragments.

\begin{tabular}{|c|c|c|c|c|c|c|c|c|c|c|c|c|c|c|}
\hline Sample & $\begin{array}{r}\text { Depth } \\
{[\mathrm{m}]}\end{array}$ & Q & $\mathrm{F}$ & Lvf & Lvi & Lvp & Lcc & Lcd & Lp & Lch & Lms & Lmi & tot & $\begin{array}{l}\text { Contribution of } \\
\text { endmembers }\left(R^{2}\right)\end{array}$ \\
\hline PM1-12 & 12.1 & 30.5 & 4.7 & 6 & & 0.5 & 14.4 & 20.8 & 3.5 & 0.2 & 19.4 & & 100 & $\begin{array}{l}50 \% \text { Brenta, } \\
20 \% \text { Cismon, } \\
30 \% \text { Piave }(0.76)\end{array}$ \\
\hline PM1-17 & 16.6 & 18.2 & 10.6 & 9.1 & 0.3 & 2.6 & 23.9 & 14.8 & 1.4 & 1.1 & 17.9 & 0.3 & 100 & $\begin{array}{l}30 \% \text { Brenta, } \\
20 \% \text { Cismon, } \\
50 \% \text { Piave }(0.80)\end{array}$ \\
\hline PM1-19 & 19.4 & 19.5 & 9.9 & 13.1 & & 2.1 & 15.5 & 19.3 & 0.6 & 1.6 & 18.4 & & 100 & $\begin{array}{l}50 \% \text { Brenta, } \\
20 \% \text { Cismon, } \\
30 \% \text { Piave (0.93) }\end{array}$ \\
\hline RB1-8 & 7.9 & 10.3 & 2.1 & 8 & & 0.3 & 47.3 & 15.3 & 1.6 & 10.1 & 5.2 & & 100 & $\begin{array}{l}\text { All combinations } \\
(<0.7)\end{array}$ \\
\hline RB1-16 & 15.7 & 25.1 & 5.5 & 7.5 & & & 18.9 & 22.5 & 4.6 & 0.5 & 15.5 & & 100 & $\begin{array}{l}40 \% \text { Brenta, } \\
10 \% \text { Cismon, } \\
50 \% \text { Piave }(0.79)\end{array}$ \\
\hline RB1-21 & 21.4 & 26.8 & 10.4 & 9.7 & & 1.7 & 5.6 & 18.9 & 1.6 & 0.7 & 24.4 & 0.2 & 100 & $\begin{array}{l}50 \% \text { Brenta, } \\
30 \% \text { Cismon, } \\
20 \% \text { Piave }(0.88)\end{array}$ \\
\hline RB1-24 & 24.45 & 19.3 & 11.1 & 11.1 & & 1.1 & 12 & 21.6 & 2.2 & 1.8 & 19.7 & 0.2 & 100 & $\begin{array}{l}50 \% \text { Brenta, } \\
20 \% \text { Cismon, } \\
30 \% \text { Piave (0.93) }\end{array}$ \\
\hline RB1-27 & 27.3 & 25.1 & 8.3 & 18.8 & 0.3 & & 3.3 & 24.3 & 2.8 & 0.5 & 16 & & 100 & $\begin{array}{l}80 \% \text { Brenta, } \\
10 \% \text { Cismon, } \\
10 \% \text { Piave }(0.94)\end{array}$ \\
\hline RB1-29 & 28.95 & 28.3 & 20.2 & 19.2 & & 1.5 & 2.5 & 6.6 & 1.1 & 1 & 19.2 & & 100 & $\begin{array}{l}100 \% \text { Brenta } \\
(0.83)\end{array}$ \\
\hline RB1-30 & 29.95 & 27.9 & 18.5 & 21.1 & & 2.6 & 7.8 & 5.3 & 0.3 & 1 & 14.1 & & 100 & $\begin{array}{l}100 \% \text { Brenta } \\
(0.83)\end{array}$ \\
\hline
\end{tabular}

ing stoichiometric mineral composition (for quartz, calcite, dolomite, feldspars, illite and kaolinite); a Fe-rich, Mg-poor dolomite was also included in the calculation (according to the XRD evidence of non-stoichiometric dolomite in almost all the samples), in addition to two Al-chlorites (Fe- or $\mathrm{Mg}$ enriched) and organic matter. The comparison between the calculated and the measured chemical composition was considered satisfactory (total least square within 10 for 29 samples over 32).

\subsection{Chemical composition}

The major elements, some trace elements (including $\mathrm{N}$ ) and the organic carbon $\left(\mathrm{C}_{\text {org }}\right)$ were determined as reported by Carraro et al. (2015). Samples were digested with concentrated $\mathrm{HNO}_{3}+\mathrm{HCl}+\mathrm{HF}$ at $140^{\circ} \mathrm{C}$ for $90 \mathrm{~min}$, then rinsed with $\mathrm{H}_{3} \mathrm{BO}_{3}$ and heated at $140{ }^{\circ} \mathrm{C}$ for $60 \mathrm{~min}$. Afterwards, the solutions were analysed by inductively coupled plasma
(ICP-OES) and atomic absorption spectroscopy (AAS). The loss on ignition (LOI) was measured after heating the sample to $860^{\circ} \mathrm{C}$ for $20 \mathrm{~min}$ and to $980^{\circ} \mathrm{C}$ for $2 \mathrm{~h}$.

An automatic elemental analyzer was used to obtain $\mathrm{C}_{\text {org }}$ and total $\mathrm{N}$ for the carbonate-free residues. The measurements were repeated at least twice using Ag sample containers.

All of the mineralogical and chemical data were used for hierarchical cluster analysis (carried out using SPSS 6.0), in order to point out sample similarities and/or anomalies. Five dark sediments were grouped in the same cluster; this group was characterized by a percentage of organic matter higher than $12 \%$. This threshold value was used for peat identification (see Carraro et al., 2015 for analytical details). Macroscopic features (black colour and fine-grained) were used for peat identification when chemical data were not available. 


\subsection{Remote sensing}

Publicly available aerial photographs and satellite images (Google Earth and Bing databases) were processed and analysed for the mapping of relict landforms. Panoramic and detail photographs were acquired during field surveys and subsequently used in conjunction with the other abovementioned images.

A digital elevation model (DEM) provided by the Regione Veneto, based on topographic data derived from $1: 5000$ topographic maps ( $5 \mathrm{~m}$ cell size and an XY accuracy of $2 \mathrm{~m}-$ http://idt.regione.veneto.it/app/metacatalog/; last access: 13 April 2018) was used. It covered the entire study area, assuring the uniform accuracy of the investigation. The various DEM tiles were assembled using ArcGIS (10.4.1 version) to allow for better processing and a more uniform visualization. All topographic profiles presented here are based on this DEM.

\section{Results}

\subsection{Field survey}

The field survey allowed for the identification of some key stratigraphic sections and outcrops that were regarded as being representative of specific sectors of the study area (see Fig. 2 for locations). Their descriptions are presented here in geographical order, from east to west and from north to south.

\subsubsection{The Seren Valley and the Roncon outcrops}

On the bottom of the Seren Valley (390 m a.s.1.) widespread outcrops of matrix-supported diamicton can be found (Fig. 2). These deposits are overconsolidated and characterized by centimetric clasts with sparse boulders, sub-rounded to angular in shape and embedded in an abundant silty matrix. In the thalweg of the Stizzone Creek, which runs along the valley, silty matrix-supported diamicton crops out, with striated clasts. Different sedimentary, volcanic and metamorphic lithologies are present in the deposit, all of which show no evident weathering. The Seren Valley deposits can be ascribed to melt-out tills, whilst those located along the thalweg are lodgment till; both of these tills belong to the Piave Glacier. In the nearby Roncon section (Fig. 2), a deposit similar to these melt-out tills was observed in a few decametric outcrops at an elevation of about $450 \mathrm{~m}$ a.s.l.

\subsubsection{The Monache ridges}

On the Monache Plateau a series of ridges, which is more than $0.5 \mathrm{~km}$ long, is present at an elevation ranging from 750 to $650 \mathrm{~m}$ a.s.l. (Fig. 2). These ridges are elongated and asymmetric in shape. This is due to the fact that they present a very steep, high downhill flank (3 to $20 \mathrm{~m}$ ), whilst the uphill side is lower and consists of a low-angle slope that rests on the bedrock. These landforms mainly consist of matrixsupported diamicton characterized by white/grey limestone clasts, which are up to $50 \mathrm{~cm}$ in size, with dark flint nodules (black and brown). All of the observed clasts are made of "Maiolica" limestone, a Lower Cretaceous formation that crops out extensively along the whole Grappa Massif (Dal Piaz et al., 1946; Carraro et al., 1989), where the ridges are located. Therefore, these ridges are interpreted as lateral moraines of the Piave Glacier that are fed by local limestones debris.

\subsubsection{The Guarda Ridge and core}

The Guarda Ridge is located on the northern side of the Canal La Menor Valley, in the Casere alla Guarda locality, at an elevation ranging from 660 to $700 \mathrm{~m}$ a.s.1. (Fig. 2). It is about $400 \mathrm{~m}$ long, up to $30 \mathrm{~m}$ high and has very steep flanks. This ridge consists of a polygenic diamicton with clasts of porphyry, limestone and siltstone, up to $50 \mathrm{~cm}$ in size, which are sub-rounded to angular in shape. Weathering of the clasts is minimal, and the material is not overconsolidated. The ridge is interpreted as a lateral moraine of the tongue of the Brenta Glacier that was flowing through the Canal La Menor Valley.

A $4.7 \mathrm{~m}$ long core (Guarda1 core) was manually drilled in the Guarda locality, at an elevation of $664 \mathrm{ma.s.1}$., on a wide valley bottom that is closed downstream by the Guarda moraine (Figs. 3 and 6). The cored sequence consists of clayey silt layers, which are grey in colour, with the sporadic presence of centimetric sandy intervals. A single $30 \mathrm{~cm}$ thick gravelly layer is present between 3.2 and $3.5 \mathrm{~m}$ b.s. (metres below surface), with sparse angular gravel clasts (3$4 \mathrm{~mm}$ in size) immersed in a sandy matrix. The Guarda1 core shows a phase of low-energy sedimentation in a confined environment, with a single high-energy event. According to the lack of deep weathering of the deposit and the presence of a poorly developed soil on top of the succession, the whole sequence is likely to have deposited in a fluvio-lacustrine basin during the late stages of LGM and/or during the Lateglacial and early Holocene; during this period the Guarda moraine was blocking the run-off from this lateral valley to the main Canal La Menor Valley.

\subsubsection{The Novegno and Col del Gallo deposits}

The top of the Novegno Plateau is characterized by a lowgradient plateau at elevations ranging from about 600 to $720 \mathrm{~m}$ a.s.1. In this area, many elongated ridges are found, which locally merge into one another, and have a general southwest-northeast direction (Fig. 2). They are up to $2 \mathrm{~km}$ long, $50 \mathrm{~m}$ wide and $40 \mathrm{~m}$ high, usually with steep slopes. The observed outcrops show that these ridges have polygenic clast compositions, are constituted by matrix-supported diamicton with clasts of porphyry, limestone and siltstone, up to $40 \mathrm{~cm}$ in size, and are sub-rounded to angular in shape (Fig. 4b). Between the ridges, as well as on the northern and 

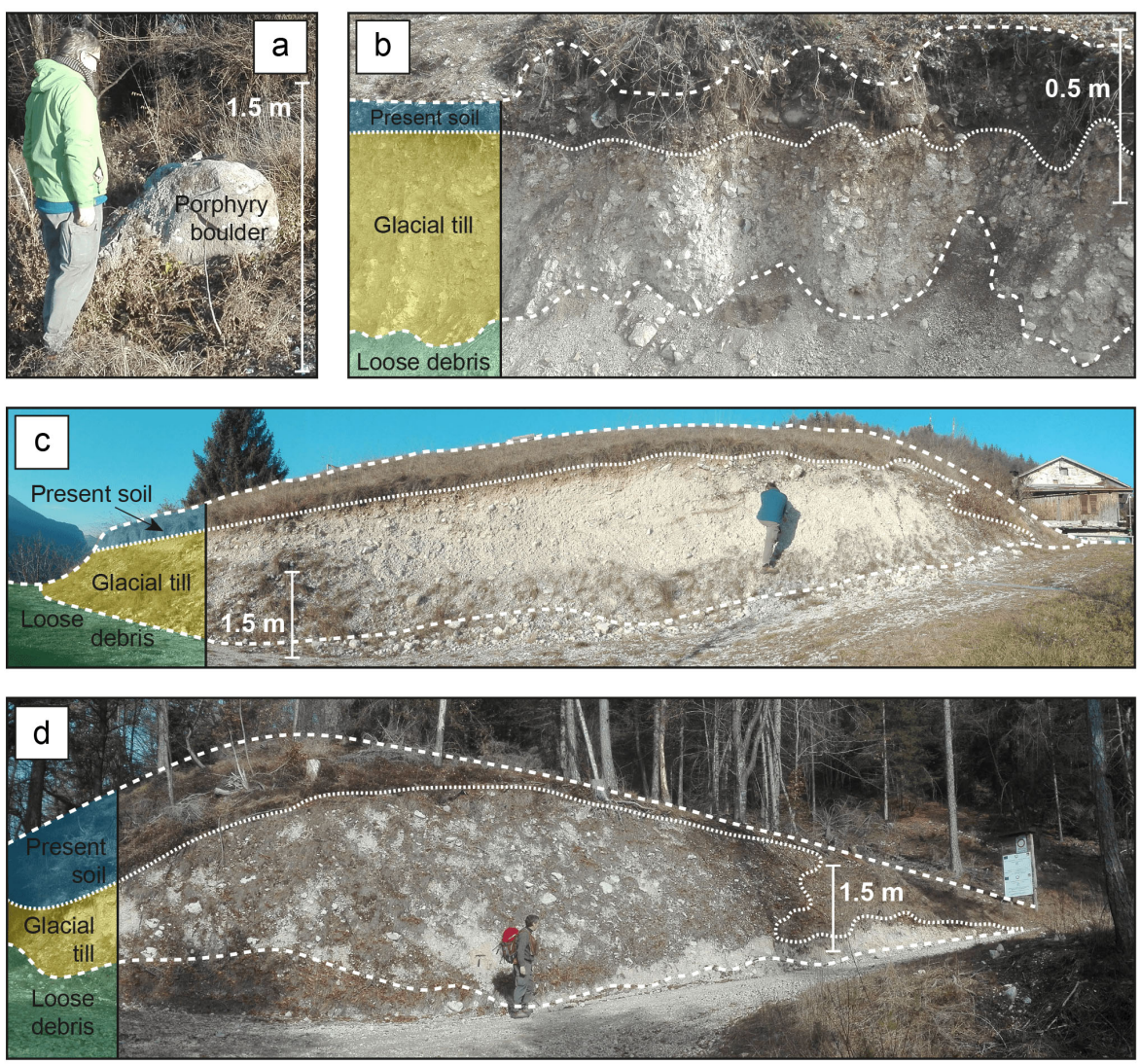

Figure 4. Photos taken in the middle sector of the Valsugana Valley. When present, stratigraphic layers are separated by dotted/dashed white lines. (a) A porphyry boulder, located on top of Col del Gallo mount; (b) a section of a lateral moraine of the Brenta Glacier, located on top of the Novegno mount; (c) a moraine, located on the southern side of the Col del Gallo; and (d) a moraine, located in the Sorist area.

southern sides of Col del Gallo (600-780 m a.s.l.), scattered patches of similar deposits can be found, which are characterized by a slightly higher matrix content (Figs. 2, 4c). The deposit is not overconsolidated and the weathering is minimal. Locally, some big boulders, up to $1.5 \mathrm{~m}$ in size, were found; these consisted mainly of porphyry (Fig. 4a) and granite. These sediments can be classified as glacial in origin, or, more specifically, as melt-out and flow tills.

On top of Col del Gallo (870 m a.s.1.), no proper outcrops are present, but centimetric clasts of volcanic and metamorphic phyllites were found in the surface soil.

All evidence shows that the Novegno Plateau is occupied by many lateral moraines formed by a glacier which was collecting material from an area located at least $25 \mathrm{~km}$ to the north, where the nearest outcrops of porphyry are found (Fig. 1). Similar glacial sediments are found on the northern and southern sides of Col del Gallo (Fig. 4c). It is likely that they relate to the same glacier. The deposits located on top of Col del Gallo are about $100 \mathrm{~m}$ higher than the other deposits and may possibly be related to a previous glacial advance.

\subsubsection{The Sorist ridges}

The Sorist mount area is a series of at least three ridges, which is more than $0.8 \mathrm{~km}$ long, at an elevation ranging from 650 to $760 \mathrm{~m}$ a.s.l. (Fig. 2). These ridges are elongated and present steep flanks, up to $10 \mathrm{~m}$ high. Locally the deposits forming these landforms crop out, showing a polygenic nature, with clasts of porphyry, limestone and siltstone, up to $60 \mathrm{~cm}$ in size; these deposits are also sub-rounded to angular in shape and embedded in an abundant matrix (Fig. 4d). Weathering of the clasts is minimal, and the material is not overconsolidated. Some large porphyry boulders, up to $1 \mathrm{~m}$ in size, were also found.

These ridges are interpreted as left moraines of the LGM Brenta Glacier, which flowed through the Valsugana Valley.

\subsubsection{The Enego Ridge}

Enego Ridge is $1 \mathrm{~km}$ long, more than $70 \mathrm{~m}$ high and is located on the western side of the Brenta Valley at an elevation of 760-790 m a.s.1., where Enego village is also situated (Fig. 2). This ridge is a lateral moraine of the Brenta Glacier, which has already been described by former scholars 
(Trevisan, 1939; Dal Piaz et al., 1946), and is considered to have formed during the LGM. These deposits are the southernmost known Brenta glacial deposits. During this particular survey, no large boulders ( $>1 \mathrm{~m}$ ) were discovered; however, a second, smaller ridge was found at lower elevation $(\sim 650$ m a.s.l. $)$.

These ridges are interpreted as the right-lateral moraines of the Brenta Glacier during the LGM.

\subsubsection{The Coste and Valstagna sections}

In the Coste area, on the western side of the Valsugana Valley bottom, about $600 \mathrm{~m}$ south of the Enego Ridge, a stratigraphic section was observed at the excavation front of a gravel pit (Fig. 5), with the base at about $210 \mathrm{~m}$ a.s.l. $(\sim 10 \mathrm{~m}$ above the present valley bottom) (Fig. 2). The section is about $50 \mathrm{~m}$ high, $100 \mathrm{~m}$ long and is composed of two main units:

- The lower unit consists of a $10-15 \mathrm{~m}$ thick gravel body rich in sandy matrix, which presents cross-toplanar stratification. Clasts are centimetric in size (maximum diameter is about $30 \mathrm{~cm}$ ), sub-rounded to subangular and mainly consist of carbonate rocks (limestones/marlstones), with abundant siltstones and some granites and porphyries. The lower boundary of this unit is not visible due to a covering of loose debris. The upper boundary with the "upper unit" shows the interfingering of the two units in the western part of the section, near the foot of the rock wall that constitutes the side of the valley.

- The upper unit begins from the top of the lower unit and stretches up to the topographic surface. It is a sedimentary body made of angular clasts, which are centimetricto-decimetric in size, with a sandy matrix and scattered boulders (maximum diameter of about $1 \mathrm{~m}$ ). This unit is crudely stratified, with bedding dipping $25-30^{\circ}$ towards the valley axis. Clasts are lithologically homogeneous, and only consist of the local carbonate rocks of the overlying rock walls.

The lower unit is attributed to fluvial deposition by the Brenta River, interfingered and superimposed by scree deposits falling from the overlying rock walls.

A similar succession was found on the eastern side of the Brenta Valley, in front of the town of Valstagna, about $9 \mathrm{~km}$ south of Coste section. Here, a $15 \mathrm{~m}$-high outcrop has been exposed by quarry activity and testifies to the occurrence of Brenta River fluvial deposits at elevations of $\sim 165$ to $170 \mathrm{~m}$ a.s.l., covered by $10 \mathrm{~m}$ of slope deposits.

\subsubsection{The Rocca deposits}

About $1 \mathrm{~km}$ north of the village of Rocca, two $20 \mathrm{~m}$-high ridges are present; the top of these ridges is $310 \mathrm{~m}$ a.s.l.

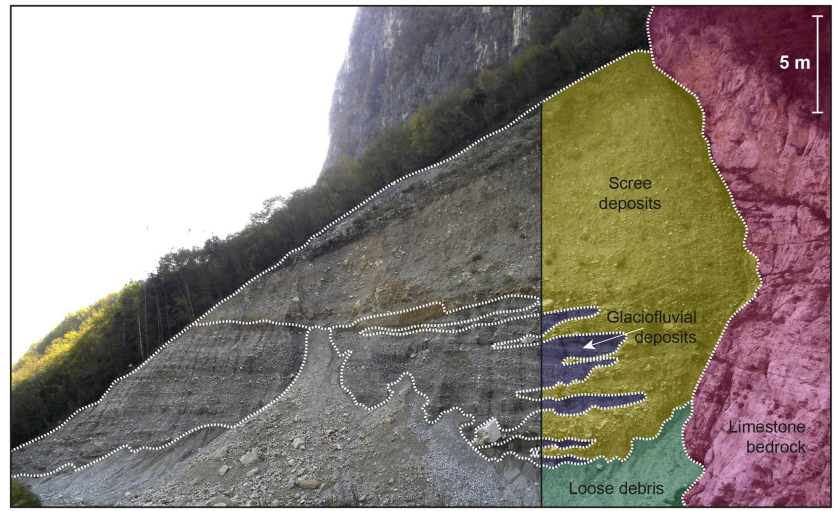

Figure 5. The Coste section. It is possible to appreciate how inclined-bedding scree deposits overlie and interfinger with horizontal-bedding glaciofluvial sediments.

(Fig. 2). The northernmost ridge is made of a sub-rounded polygenic matrix-supported diamicton with clasts up to $20 \mathrm{~cm}$, which are sub-rounded to angular in shape. These ridges are interpreted as frontal moraines of a glacier tongue flowing into the Canal La Menor Valley.

The town of Rocca is built upon carbonate bedrock, but a small patch of sediments crops out next to the local graveyard (Fig. 2). This deposit consists of a matrix-supported diamicton with sub-rounded clasts, up to $30 \mathrm{~cm}$ in size, which are sub-rounded to angular in shape. The clasts are minimally weathered and mainly carbonate, although porphyry clasts are also present. The abundant matrix is mainly constituted by sandy particles.

These deposits are interpreted as LGM till deposited by a glacier tongue flowing into the Corlo Valley, where the artificial lake is currently located.

\subsection{Remote sensing}

Whilst investigation of aerial and satellite images was not very profitable due to the dense vegetation coverage, the DEM provided very valuable data. The DEM allowed for the lateral tracing of those scattered landforms already recognized in the field, such as the Enego moraine, and for the mapping of other new landforms, based on morphological similarity. In particular, many moraines belonging to the Novegno group were mapped using this approach.

\subsection{Alluvial plain cores}

Cores are described here as lithofacies assemblages, from the bottom up. The depth of the various layers is referred to from the top of the core (indicated by the acronym "b.s." - below surface). Detailed logs are presented in Fig. 6. Data concerning the samples collected for radiocarbon dating are summarized in Table 1; the reader can refer to the specific core 
descriptions for details on the positions of the samples in the stratigraphy.

\subsubsection{RB1 core}

The RB1 borehole was drilled in the Brenta megafan near the town of Carturo, about $5 \mathrm{~km}$ north of Piazzola sul Brenta (see Fig. 3 for location and Fig. 6 for the stratigraphic log), at a topographic elevation of $30 \mathrm{~m}$ a.s.l.

The basal part of the core is made of an alternation of sand bodies and silty and clayey layers with varying sand content. The sand is normally well sorted, and is made up of grains that are a maximum of $0.5 \mathrm{~mm}$ wide. Six thin $(6-18 \mathrm{~cm}$ thick) very fine-grained intervals characterized by high organic content are present. Three almost equally spaced layers (27.5, 21.8 and $9.3 \mathrm{mb}$ b.s.) were radiocarbon dated to 26.6 $27.3,25.7-26.1$ and $22.6-23.2 \mathrm{kacal} \mathrm{BP}$, respectively.

At about $9 \mathrm{mb}$.s. a clear erosional surface is present, marked by an abrupt transition from clayey silt to a coarsening upward sequence from medium sand to coarse gravel, which is sub-angular to sub-rounded (largest clasts are about $2 \mathrm{~cm}$ ). A single, $15 \mathrm{~cm}$-thick silty layer interrupts this succession at $7.85 \mathrm{~m}$ b.s. The uppermost $2.5 \mathrm{~m}$ of the core is constituted of a fining upward sequence of sandy and silty layers. No clear evidence of the modern soil was found at the top.

The core is interpreted as sandy proximal overbank deposits, intercalated with more distal overbank fines indicative of low-energy floodplain deposition. Locally, some intra-ridge swampy areas developed, inducing the formation of peat layers where organic deposition prevailed over minerogenic contribution, as was common in the southeastern Alpine piedmont during the LGM (Miola et al., 2006; Rossato and Mozzi, 2016). The coarsening upward sequence is ascribable to sandy-gravelly channel sediments that eroded the older deposits at the end of the LGM and formed fluvial incised valleys through the whole Brenta megafan (Mozzi et al., 2013). Finally, the top of the core consists of lower energy channel deposits or proximal overbank sandy and silty fines.

\subsubsection{PM1 core}

The PM1 core was drilled about $1 \mathrm{~km}$ west of the town of Piazzola sul Brenta, at an elevation of $27 \mathrm{~m}$ a.s.l. (see Fig. 3 for location and Fig. 6 for stratigraphic log).

The entire core is quite homogeneous, and is composed of an alternation of silty layers, with a variable content of clay and sand, interbedded with fine sand intervals. The sand is normally well sorted, with a maximum grain size of $0.5 \mathrm{~mm}$. Two layers of medium sand located at 19-20 and 16.3$17.2 \mathrm{~m}$ b.s. are the only exception to this rather monotonous sequence. Three thin $(10 \mathrm{~cm}$ maximum) layers with a very high organic content are present in the uppermost $15 \mathrm{~m}$ of the succession, two of which have been radiocarbon dated to 23.2-23.7 (13.45 m b.s.) and 19.9-20.4 (9 m b.s.) ka cal BP, respectively. The uppermost $2 \mathrm{~m}$ of the core shows evidence of a well-developed soil, constituted of pedogenic horizons $\mathrm{C}, \mathrm{Bk}$ and $\mathrm{Bw}$, from the bottom up. The entire sequence is topped by a $0.5 \mathrm{~m}$ thick anthropogenic landfill made of gravels with a silty matrix.

As in core RB1, the whole sequence can be interpreted as sandy proximal overbank sediments intercalated with finer floodplain deposits. Locally, peat deposition took place when minerogenic contribution was very low, as was also found in RB1 core. The topmost soil has characteristic calcic horizons (Calcisol after FAO, 1998), which allow its correlation to the "caranto paleosol" that developed on top of the LGM deposits in the whole Venetian area (Mozzi et al., 2003; ARPAV, 2005; Donnici et al., 2011).

\subsection{Sand petrography}

The results of the petrographic analysis of the sand fraction (and the related statistics) of cores RB1 and PM1 are reported in Table 2 and Fig. 7. According to the distribution in the biplot diagram (Fig. 7a) samples clustered in different sectors allow two petrofacies (A and B) to be distinguished, with a single sample (RB1-8) clearly differentiated by a carbonaticlastic composition.

Samples related to petrofacies A belong to the RB1 core below the peat layer at $27.5 \mathrm{mb}$ b. Sandy grains are mainly quartz, feldspar and lithic fragments $(>30 \%$ of which are volcanic), whereas the carbonate fragments are scarce and account for around $10 \%$ of the sandy grains (Fig. 7b). No sediments belonging to this petrofacies have been found in the PM1 core.

Petrofacies B is clustered towards the centre of the biplot. Although the spectrum of lithic fragments contained in this petrofacies is similar to that of petrofacies A, petrofacies B contains more carbonate clasts (Fig. 7c), generally above $35 \%$, and sedimentary lithic fragments (Fig. 7d). Micritic limestone fragments are also particularly common. Petrofacies $\mathrm{B}$ in the RB1 core starts above the $27.5 \mathrm{~m}$ b.s. peat, beginning with the RB1-27 sample (Fig. 6). All samples from the PM1 core belong to petrofacies B.

The outlier sample was ascribed to petrofacies C. This sample displayed a composition dominated by carbonate ( $>60 \%$ of the total amount) and cherts $(10 \%)$, which are normally embedded in the micritic limestones as nodules (Barbieri and Grandesso, 2007). However, this sample also had the lowest amount of quartz $(10 \%)$ and all of the other parameters, which were below $10 \%$.

These results, compared with the present-day sands of the Brenta, Cismon and Piave rivers (Garzanti et al., 2006; Monegato et al., 2010), show that petrofacies A (RB1-29 and 30) is shifted towards the felsic volcanic component. No modern river shows a petrofacies such as this. Conversely, petrofacies B matches well with the modern Brenta River, which includes the Cismon catchment. Ternary diagrams show a 


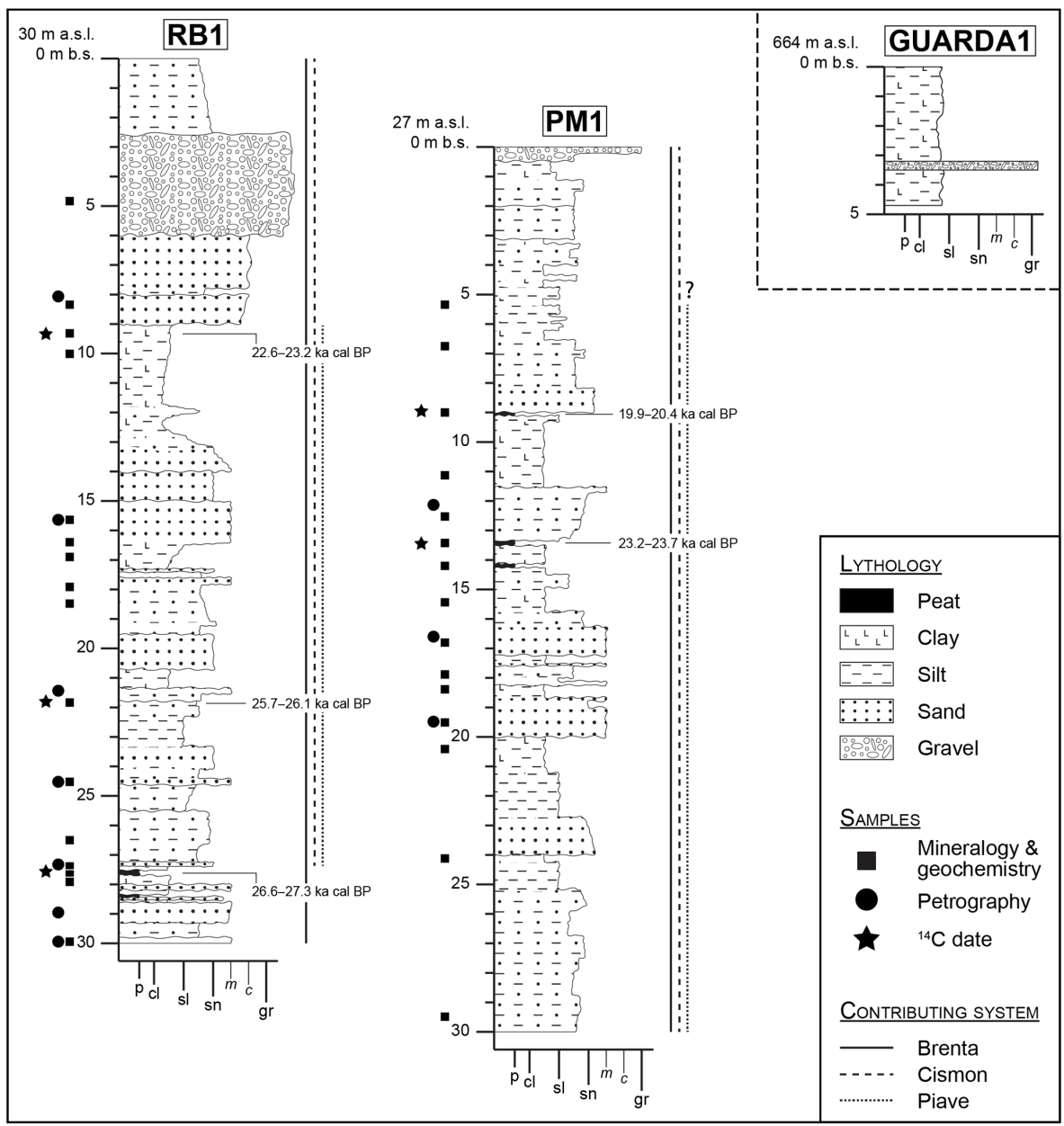

Figure 6. Stratigraphic logs of the RB1, PM1 and Guarda1 cores. Different catchments contributing to the sedimentation are marked by lateral solid/dashed lines. Samples are shown using different symbols according to the technique that was adopted.

slight shift of petrofacies B towards carbonate components (Fig. 7).

Using the mixing technique of Vezzoli and Garzanti (2009), petrofacies A was confirmed to be the most similar to the Brenta River sediments upstream of the junction with the Cismon River. Petrofacies B is quite similar to the present Brenta River, with an enrichment of carbonate rock fragments that suggests the contribution of a catchment rich in these components. This input could be from the Piave drainage basin; however, input from the Astico-Bacchiglione system in the lowlands can be discarded as the river was pushed to the west by the development of the Brenta megafan during the LGM (Rossato et al., 2013; Fontana et al., 2014), which also managed to dam Lake Fimon south of Vicenza (Monegato et al., 2011). Finally, petrofacies $\mathrm{C}$ shows high values of carbonate and chert fragments (Table 2) and no similarity to the endmembers. The mixing technique used rules out any possible scenario involving modern endmembers $\left(R^{2}<0.7\right.$; Table 2). Petrofacies $\mathrm{C}$ belongs to the filling of a post-glacial incision of the Brenta megafan (Mozzi et al., 2013), when only the Brenta and Cismon catchments were contributing. Most of the carbonate clasts are micritic limestones that, coupled with the abundance of cherts, suggest an erosion event/phase in the lower Cismon (Corlo) Valley north of Rocca (Figs. 1, 3 ) or in the upper Cismon Valley close to Lamon, where these rocks are dominant (Tessari, 1973).

\subsection{Mineralogy and geochemistry}

Mineralogical analyses of the bulk sediments related to the petrofacies of the cores are reported in terms of main minerals, such as phyllosilicates (mainly micas and chlorites), dolomites (two different crystal chemical terms) and feldspars (plagioclase and k-feldspar), as shown in Fig. 8a. The complete dataset, including mineralogical and geochemical data, is reported in the Supplement (Table S1).

Basal sediments in the RB1 core (i.e. the three deepest samples and a peat sample) are characterized by an enrichment of feldspars and correspond to petrofacies A. The over- 

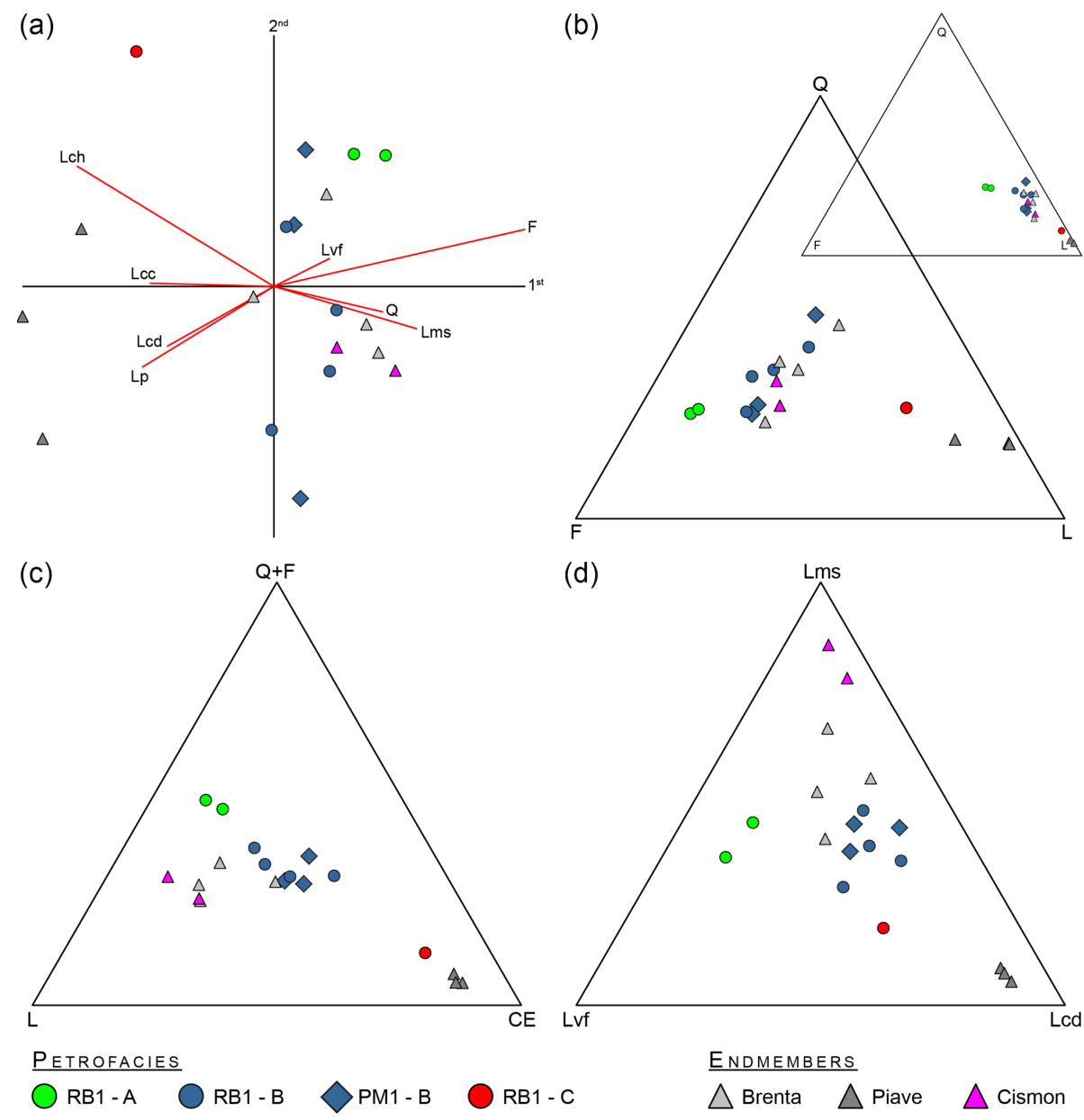

Figure 7. (a) Compositional biplot of the principal components. (b) The original (small) and centred (large) QFL diagrams. (c) The Q+F, L (non-carbonate lithic) and CE (carbonate lithic and cherts), and (d) Lms, Lvf and Lcd ternary diagrams showing the results of the sand petrography analyses performed on the RB1 and PM1 cores. Endmembers following Garzanti et al. (2006) and Monegato et al. (2010). See Table 2 for component acronyms.

head sediments, below the main erosional surface along the core, are characterized by an abundance of phyllosilicates, whereas dolomites are depleted; the stratigraphic position of these sediments corresponds to petrofacies B. The two topmost samples (above the erosional surface) are distinctive due to their higher dolomite content, and correspond to petrofacies $\mathrm{C}$.

Samples from the PM1 core mainly plot as those recognized for petrofacies B in the RB1 core, without significant stratigraphic differences along the PM1 core. Whilst calcite is one of the main minerals observed in the cores, it is not considered to be a discriminating variable because it is strongly depleted or even absent in peat sediments (i.e. $>12 \mathrm{wt} \%$ organic matter); therefore, this mineral is deemed to be mainly influenced by the depositional environment and poorly indicative of the sediment provenance.

The distinctive mineralogical features of samples corresponding to petrofacies $\mathrm{A}, \mathrm{B}$ and $\mathrm{C}$ are also evidenced by sediment chemistry, as reported in Fig. $8 \mathrm{~b}$ in terms of $\mathrm{MgO}$,
$\mathrm{Na}_{2} \mathrm{O}$ and $\mathrm{Fe}_{2} \mathrm{O}_{3}$, because of their affinity for dolomite, plagioclases and fine-grained minerals (clay minerals, oxides and hydroxides). In this case, petrofacies A, B and C are even more clearly discriminated for both cores.

A more detailed evaluation of the bulk mineralogical composition along the RB1 core highlights the fact that both samples corresponding to petrofacies A, B and C are characterized by a peculiar feldspar/quartz ratio (Fig. S1 in the Supplement), and that the transition between each group is rather sharp. Conversely, the feldspar/quartz ratio throughout the PM1 core does not show abrupt variations.

\section{Discussion}

Data gathered in the mountainous areas of this study and in the piedmont megafan are discussed here in order to reconstruct the evolution of the LGM Brenta Glacier and the tributary glacial systems. 


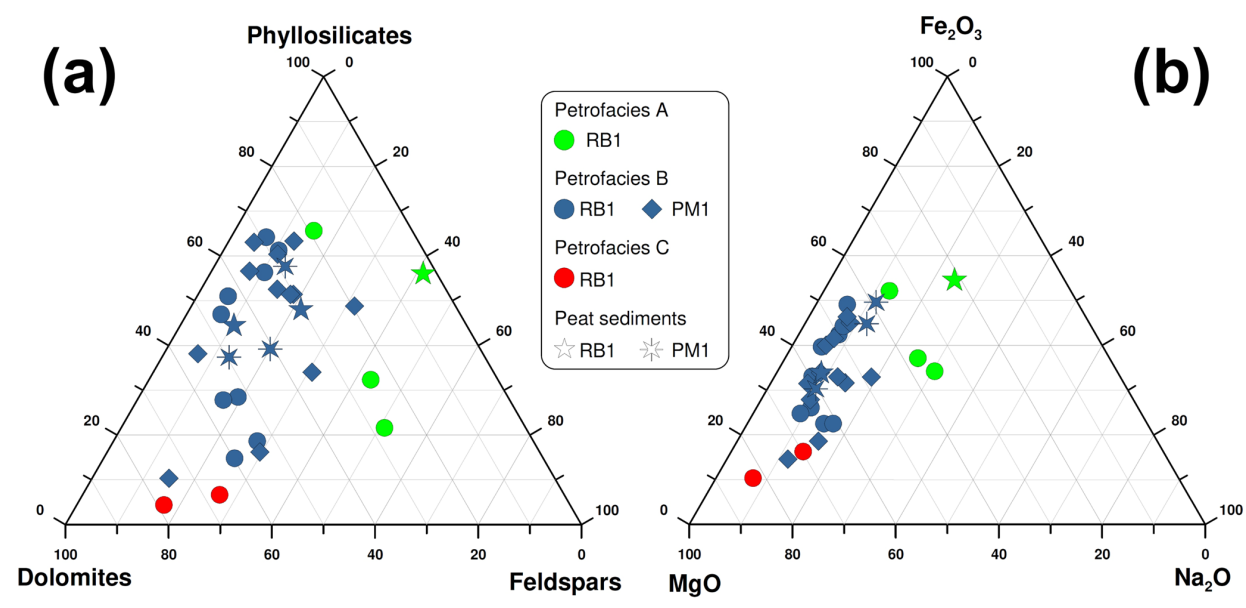

Figure 8. Ternary diagram reporting the main selected mineral components (a) and geochemical components (b) of the bulk sediments in the RB1 and PM1 cores. Peat samples are represented by the two star-like symbols.

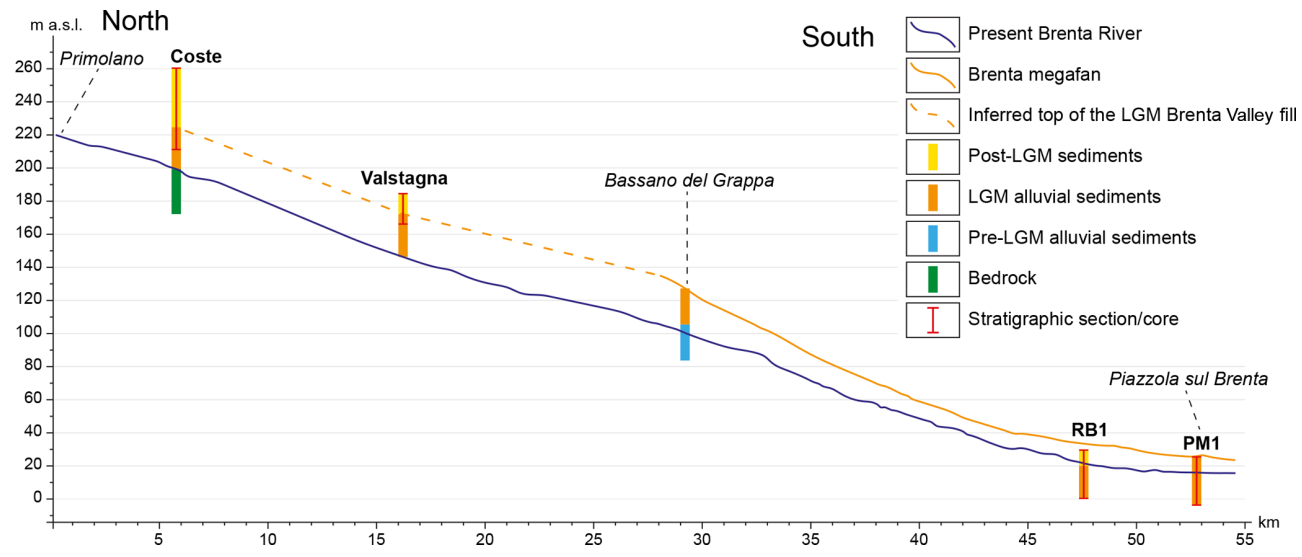

Figure 9. Longitudinal profiles of the present Brenta River (blue solid line), from Primolano to Piazzola sul Brenta, including the Brenta megafan (orange solid line), from the apex to Piazzola sul Brenta, and the possible profile of the Brenta Valley bottom during the LGM (orange dashed line), inferred from stratigraphic sections. The age of sediments/bedrock is shown using different colours.

\subsection{Glaciers in the mountainous study area}

While all the major LGM valley glaciers of the southeastern Alps preserved all or parts of their end-moraine systems in the terminal valley tracts and/or in the piedmont plain (Venzo et al., 1977; Monegato et al., 2007; Carton et al., 2009; Rossato et al., 2013), in the Brenta Valley there is no evidence of the LGM (nor older) terminal moraines (Castiglioni, 2004). The Brenta Glacier that used to flow through the Valsugana during the LGM was mainly fed by the Adige Glacier, the largest glacier on the southern side of the Alps (Bassetti and Borsato, 2005; Monegato et al., 2017), and some local tributary glaciers from the eastern side of the valley. The transfluence of Adige Glacier into the Valsugana was through the Fersina saddle (550 m a.s.1.), the Vigolo Vattaro wind gap (lowermost altitude: $680 \mathrm{~m}$ a.s.l.) and, more significantly, above the Calisio Plateau (ca $1000 \mathrm{~m}$ a.s.l.) during the maximum glacier expansion. Flowing for about $50 \mathrm{~km}$ along the Valsugana, the glacier reached the Primolano sector where the Valsugana narrows from about $1 \mathrm{~km}$ to $100 \mathrm{~m}$ and the Canal La Menor wind gap opens eastwards at about 350 m a.s.l. (Fig. 2).

Based on the location of marginal glacial deposits, the sudden narrowing of the Brenta Valley may have caused the glacier front to stabilize, which is known to have occurred in the northwestern Himalayas during the late Pleistocene, when narrow steep-walled canyons constituted an effective barrier to glacial advance (Burbank and Fort, 1985). The subsequent growth of the glacier forced it to rise up to the Canal La Menor wind gap and split into two lobes (Fig. 2). The eastern lobe flowed across the wind gap and formed the Sorist (650 to $760 \mathrm{~m}$ a.s.1.), Novegno (600 to $720 \mathrm{~m}$ a.s.1.) and Guarda (660 to $700 \mathrm{~m}$ a.s.l.) lateral moraines, whilst the western lobe built the Enego and Col del Gallo (both $\sim 780 \mathrm{~m}$ a.s.l.) lateral moraines. The abundance of porphyry clasts and boulders in the deposits related to both the east- 
ern and western lobes indicates sediment provenance from the upper Valsugana and the Adige valleys. The differences in elevation of the various moraines suggest that the western lobe grew more than the eastern lobe, possibly bulging due to the narrowing of the Valsugana. A secondary effect of the glacier bulging would have been the formation of transverse crevasses, which would have caused the fall of supraglacial debris into the ice mass; both of these processes would have hindered the transport of sediments to the glacier front and increased the hydraulic conductivity of the otherwise effectively impermeable glacier ice (Gulley and Benn, 2007). At the end of the gorge the Valsugana Valley widens again, a morphology that likely induced the formation of splaying/radial crevasses and icefalls in the frontal glacier mass (Nye, 1952; Harper et al., 1998; Colgan et al., 2016).

The large stratigraphic section in the Coste quarry (and the minor Valstagna section) displays no evidence of glacial deposits, while it indicates the presence of important LGM glaciofluvial aggradation in front of the western glacier's fronts. Henceforth, the front of the Brenta Glacier flowing in the main valley (western lobe) should have been located between the southernmost end of the Enego and Col del Gallo moraines and the Coste quarry. Glaciers confined in narrow valleys normally experience rapid advances under positive mass balance conditions: the narrower the valley, the faster the glacier's speed (e.g. Egholm et al., 2011). However, it has been proved that narrowing valleys promoted glacier blockage in the Himalayas during late Pleistocene (Burbank and Fort, 1985). This is believed to have been the case for the Brenta tongue, with the Coste section only being about $250 \mathrm{~m}$ downstream of the Enego moraine. The presence of the high-elevation lateral moraines hanging above the valley (the Enego moraine is about $550 \mathrm{~m}$ higher than the present valley floor) at such a short distance from proglacial sediments suggests that the glacier's front probably consisted of an icefall when the glacier was at its maximum size. The tongue of the Brenta Glacier, being a debris-free glacier, has been characterized by a more effective ablation due to solar energy compared to glaciers covered by several centimetres or more of debris (Lardeux et al., 2015; Wei et al., 2010). The resulting abundant meltwaters fed a welldeveloped proglacial stream, inducing aggradation along the whole Brenta Valley, as evidenced by the Coste and Valstagna sections. The development of a subglacial/englacial drainage system related to debris-filled crevasses probably controlled the seasonal variation of the glacier and resulted in fewer fluctuations at the glacier's front (van der Veen, 2007). Such stability would have resulted in the Enego and Col del Gallo lateral moraines growing. This Brenta Glacier tongue may have brought debris at its front both during stability, through supra- and/or englacial transport (Barr and Lovell, 2014 and reference therein), and while advancing, bulldozing pre-existing valley-floor sediments (e.g. Winkler and Matthews, 2010). Such debris may have formed end moraines, which were later eroded by post-glacial fluvial and slope processes. However, considering the narrow gorge that hosted the glacier front, it seems more probable that highdischarge proglacial streams occupied the entire gorge and continuously removed the incoming debris and precluded the formation of terminal moraines.

When the Brenta Glacier reached the elevation of the Canal La Menor wind gap, the eastern path became an effective glacial flux, which is known to occur when stabilized valley glaciers can extend laterally (Barr and Lovell, 2014). The higher the glacier, the more effective the glacial flux through the eastern path would have been, which would have even allowed the glacier to exceed the western side of the Novegno Plateau. As glacial sediment transport is likely to follow the main glacial flux, the eastern flow probably subtracted increasingly higher portions of the glacially transported debris to the western flow, depleting the sedimentary flux through the Valsugana Gorge and further hindering the formation of an end moraine at the western front. The eastern glacial lobe flowed along the Canal La Menor wind gap down to the confluence with the Corlo Valley. Here, it merged with the glacier coming from the northeast, formed by contributions from both the Cismon Glacier and the westernmost lobe of the Piave Glacier, as evidenced by the Roncon till. The Roncon till is polygenic, with pebbles of dolostones and Triassic volcanic rocks belonging to the Piave catchment. This till also crops out extensively in the nearby Seren Valley, which had a lateral tongue of the Piave Glacier flowing through it. Geomorphic evidence of the westward flow of Piave Glacier is provided by the lateral moraines at Monache (650 to $750 \mathrm{~m}$ a.s.1.), even though they are mostly made of limestone clasts; thus, they reflect a local glacigenic sedimentary input.

The glacier, which was derived from the merging of the eastern Brenta lobe and the Cismon/Piave glaciers at the confluence of Canal La Menor and the Corlo valleys, left no traces of frontal moraines. Glacial till crops out close to Rocca (Fig. 2) and till patches have been described about $0.5 \mathrm{~km}$ south of Rocca (Dal Piaz et al., 1946), suggesting that the front of this glacier was located at the beginning of the narrow gorge now occupied by the southern end of the artificial Lake Corlo. The geomorphological setting is very similar to the western tongue, suggesting that the glacier's front may also have consisted of an icefall with deep crevasses without terminal moraines at this location.

The Valsugana Glacier left a remarkably small amount of erratics. During the survey for this study, a total number of seven boulders made of porphyry and granite, up to $1 \mathrm{~m}$ in size, were found (in the Novegno and Sorist areas). Other authors have mentioned erratics on top of the Novegno Plateau (up to $2 \mathrm{~m}$ in size and made of crystalline rocks), next to the Enego moraine ("very large" boulders made of carbonate rocks; Secco, 1883; Venzo, 1940) and on the Canal La Menor Valley bottom ("extremely large" porphyry boulders; Taramelli, 1882). However, no erratics have been found, nor mentioned, downstream along the Valsugana Valley bottom. 


\subsection{The fluvial record of the glaciers' changes}

The fluvial sediments cropping out in the Coste and Valstagna quarries are the only remnants of the LGM glaciofluvial aggradation that took place downstream of both the eastern and western glaciers' fronts. This glaciofluvial sedimentation led to the infilling of the Valsugana Valley bottom up to some tens of metres above the present Brenta River. The elevation of the top of the LGM valley fill at Coste (about $225 \mathrm{~m}$ a.s.1.) is consistent with that of the Valstagna section (about $175 \mathrm{~m}$ a.s.1.) as well as with the top LGM surface of the Brenta megafan southeast of Bassano del Grappa (about $130 \mathrm{~m}$ a.s.1.). This allows for the correlation of these depositional top surfaces and the related sediments, as well as the reconstruction of the longitudinal profile of the LGM Brenta Valley bottom (Fig. 9). The LGM fluvial aggradation was followed by the incision of the valley bottom and the piedmont megafan at around $17.5 \mathrm{kacalBP}$, as the fluvial system reacted to the downwasting of the glacial system (Mozzi, 2005; Fontana et al., 2014; Rossato and Mozzi, 2016).

The growth/collapse of glacier tongues and modifications to the fluvial networks can be detected from changes in the mountain catchments and in the alluvial plain. Sedimentary systems developing at the mouth of major valleys are highly valuable databases of sedimentary, climatic and tectonic data (e.g. Mozzi, 2005; Carton et al., 2009; Pini et al., 2009; Piovan et al., 2012; Rossato and Mozzi, 2016). The paucity of radiocarbon datable material usually available in glacial deposits can be balanced with the abundant organic samples that can be collected in fluvial sedimentary sequences of this area. In this investigation, the petrographic, mineralogical and geochemical analyses of the RB1 and PM1 cores in the glaciofluvially fed Brenta megafan, chronologically framed through radiocarbon dating, integrate the evidence obtained in the mountainous area of this study. This allows for specific evolutionary phases in the drainage network feeding the Brenta megafan to be distinguished (Fig. 10). They are described in the following from oldest to youngest:

The first phase, seen in the RB 1 core, corresponds to petrofacies A and lasted until just after $27 \mathrm{kacal} \mathrm{BP}$. At that time glaciers were growing at the onset of the LGM (Monegato et al., 2007, 2017; Ivy-Ochs et al., 2008; Preusser et al., 2011), and the mountain drainage systems began to modify. The Brenta megafan sedimentation rates were still comparable with pre-LGM rates (Rossato and Mozzi, 2016). Sediments indicate that this megafan was fed by a river with a drainage system limited to the Valsugana, as shown by the petrographic samples (RB1-29 and 30). The Cismon drainage system, which is currently merging with the Brenta system, was not contributing, as it was probably flowing eastwards into the Piave system (Fig. 10).

The beginning of the second phase coincided with a gradually increasing change in the drainage system, as evidenced by mineralogical and petrographic analyses of petrofacies $B$ (samples RB1-27, 24, 21 and 16 and PM1-19, 17 and 12)
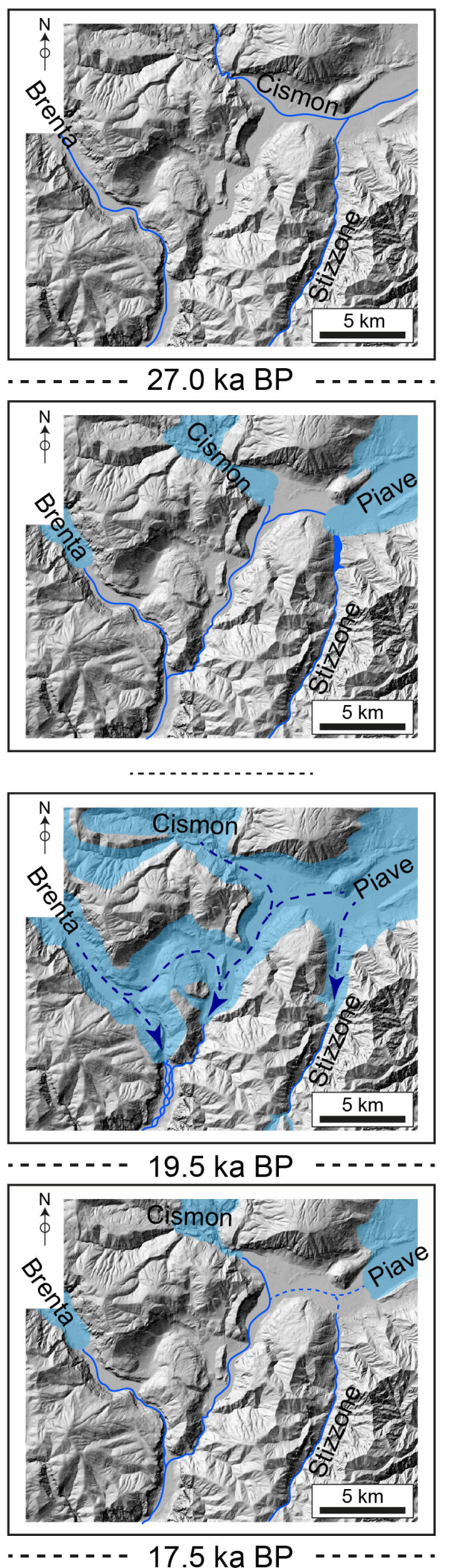

Figure 10. Evolution of the middle sector of the Valsugana Valley since the onset of the LGM; see text for details. 
(Figs. 7-8). Radiocarbon dates indicate that this phase started just after $27 \mathrm{ka} \mathrm{cal} \mathrm{BP}$ and continued until after $20.1 \mathrm{ka} \mathrm{cal} \mathrm{BP}$ (Fig. 6). The lack of major unconformities in the succession of the PM1 core suggests that the top of this phase corresponds to the LGM surface of the Brenta megafan, which implies that sedimentation lasted until $17.5 \mathrm{ka}$ cal BP (Rossato and Mozzi, 2016). Soon after $27 \mathrm{kacal} \mathrm{BP}$, the Piave and Cismon systems began to contribute to the Brenta system through the Corlo Valley. Whilst the Cismon River diversion does not require a direct connection with glacier dynamics, the Piave Glacier must have grown enough to overcome the Seren saddle ( 2330 ma.s.l.; Figs. 1, 10), which is about $100 \mathrm{~m}$ above the current Piave Valley bottom. At the acme of the LGM, the contribution of these systems is likely to have greatly increased the sedimentation rates in the Brenta megafan, which nearly doubled in the 26.723.8 ka cal BP period (Rossato and Mozzi, 2016; Fig. 10). The Piave Glacier tongue, having overcome the Seren saddle, probably survived the $\sim 19.5 \mathrm{ka}$ cal BP glacial retreat, as the main glacier was still $500 \mathrm{~m}$ thick near Belluno ("Val Piana" stage: $16210 \pm 50$ years BP, Pellegrini et al., 2005, recalibrated to 19386-19772 years cal BP with IntCal13 calibration curve, Reimer et al., 2013).

The youngest phase is only recorded in the topmost sediments of the RB1 core, and constitutes petrofacies C. It is ascribable to the infilling of a fluvial entrenchment (Fig. 2) developed during the late stages of deglaciation (Mozzi et al., 2010, 2013), which has also been seen elsewhere throughout the central and eastern Po Plain (Fontana et al., 2014). Mineralogy confirms the present configuration of the drainage system, with the Cismon River flowing into the Brenta River through the Corlo Valley and the Piave River already flowing along its modern valley. However, a remarkable enrichment of carbonates (micritic limestones) with respect to modern Brenta sediments, evidenced by petrography, mineralogy and geochemistry, highlights an anomalous setting. Two possible scenarios may be proposed to explain a signal such as this: (i) a significant bedrock erosion of these lithologies in the mountainous area of this study (i.e. especially in the Cismon catchment), or (ii) a connection with the dismantling of the postulated landslide that induced the aggradation of the Lamon terraces (if the "landslide scenario" is assumed; see the Section 2 of this paper for details). The first hypothesis could relate to the carving of the Corlo Valley by the Cismon River during the Lateglacial when high meltwater discharges could easily induce such enhanced erosion stages, which normally occurs during glacier recessional phases (Herman et al., 2011).

\section{Conclusions}

The acquired dataset casts new light on the dynamics of the LGM glaciers in the canyon-like middle tract of a major Alpine valley, the Valsugana. The knot of the Valsugana
Glacier has been disentangled for the first time, indicating a singular configuration of the glacier snouts crossing narrow and deep valley reaches.

Our data indicate that the Brenta Glacier split at Primolano at the LGM acme. One tongue flowed southwards along the Valsugana Valley through a narrow gorge which prevented an effective glacier flux and caused the glacier to bulge. This bulging forced the right side of the glacier tongue to reach high elevation at Enego, while its front was probably constituted by an icefall located just upstream of Coste. Meltwaters flowed in subglacial and englacial streams removing debris from the glacier front and filling the Valsugana Valley bottom. The other tongue collected most of the glacial and debris fluxes, and flowed eastwards along the Canal La Menor Valley before joining the Cismon/Piave glaciers near Rocca.

The coupling of data gathered in the mountainous area of the study site with those collected in the piedmont alluvial plain allows a coherent reconstruction of the dynamics of the LGM glacier tongues. Prior to the arrival of the glacier fronts in the study area, the Brenta megafan only received sediments from the upper Valsugana catchment. A major alteration of the drainage system occurred just before $27 \mathrm{ka}$ cal BP, when the Cismon and Piave systems joined the Brenta River in the Valsugana Valley, through the Seren saddle and the Corlo Valley. Between $\sim 27$ and, at least, $19.5 \mathrm{ka}$ cal BP, the Brenta, Cismon and Piave glaciers merged in the surroundings of the Novegno mount. Their meltwaters built up the largest alluvial landform on the Po Plain at that time: the Brenta megafan. At the end of the LGM, the waning of glaciers induced the fluvial incision of the Brenta megafan. The abundance of micritic carbonates in the sedimentary fill of incisions such as that near Piazzola sul Brenta suggests concomitant remarkable bedrock erosion in the Corlo Valley and/or the reworking of sediments from the Cismon catchment at Lamon.

As general conclusive remarks, this study highlights the following:

- The narrowing of a main glaciated valley may result in the blockage/slowing of the glacier flux. A larger lateral valley may easily represent an alternative path for the glacier, even if its bottom lies at higher elevation, subtracting a large part of the glacial and debris flux from the main valley.

- Valley glaciers flowing across narrow gorges may be subject to bulging and likely have icefalls at their front, while proglacial meltwater streams prevent the formation of end moraines.

- In rugged Alpine terrains, glacial catchments may significantly vary over time during a single glaciation. Such changes affect both the glacial and glaciofluvial systems and can be recognized in the alluvial stratigraphic record far downstream from the glacier front. 
Sand petrography and chemical/mineralogical composition of sediments are good tracers of glacial catchment variations.

Data availability. All data associated with this article, when not explicitly cited, were collected by us and are described in the text or in the Supplement.

Supplement. The supplement related to this article is available online at: https://doi.org/10.5194/esurf-6-809-2018-supplement.

Author contributions. All authors contributed to interpreting the results and improving the text, which was primarily written by SR. Each author contributed to different sections of the text: the field survey was undertaken by SR, GM and PM; the sand petrography was carried out by GM; the X-ray diffraction was undertaken by $\mathrm{AC}$ and FT; the chemical composition was carried out by AC and FT; the core descriptions were carried out by SR and PM; and the remote sensing was carried out by SR.

Competing interests. The authors declare that they have no conflict of interest.

Acknowledgements. We sincerely thank Stefan Winkler and Laura Stutenbecker for thorough critical reviews that greatly improved the quality of the paper.

Edited by: David Lundbek Egholm

Reviewed by: Stefan Winkler and Laura Stutenbecker

\section{References}

Aitchinson, J. and Greenacre, M.: Biplots of compositional data, J. Roy. Stat. Soc. C-App., 51, 375-392, https://doi.org/10.1111/1467-9876.00275, 2002.

ARPAV: Carta dei suoli del Veneto in scala 1: 250.000, Grafiche Vianello, Treviso, 2005.

Avanzini, M., Bargossi, G. M., Borsato, A., and Selli, L.: Note Illustrative della Carta Geologica d'Italia alla scala 1: 50.000, foglio 060- Trento, ISPRA-Servizio Geologico d'Italia, Trento, 2010.

Baratto, A., Ferrarese, F., Meneghel, M., and Sauro, U.: La ricostruzione della glaciazione wurmiana nel Gruppo del Monte Grappa (Prealpi Venete), in: Risposta dei processi geomorfologici alle variazioni ambientali, edited by: Biancotti, A. and Motta, M., G. Brigati, Genova, Italy, 67-77, 2003.

Barbieri, G. and Grandesso, P.: Note illustrative della Carta Geologica d'Italia alla scala 1: 50.000, foglio 082-Asiago, APAT, S.EL.CA., Firenze, 135, 2007.

Barr, I. D. and Lovell, H.: A review of topographic controls on moraine distribution, Geomorphology, 226, 44-64, https://doi.org/10.1016/j.geomorph.2014.07.030, 2014.
Bartolomei, G.: Nuovi elementi su un morenico antico a Bassano del Grappa, Vicenza, in: Studi geografici e geologici in onore di Severino Belloni, edited by: Orombelli, G., 9-18, 1999.

Bartolomei, G., Corsi, M., Dal Cin, R., D’Amico, C., Gatto, G. O., Gatto, P., Nardin, M., Rossi, D., Sacerdoti, M., and Semenza, E.: Note illustrative della carta geologica d'Italia alla scala 1: 100.000, foglio 021-Trento, Poligrafica e Cartevalori, Ercolano, 1969

Bassetti, M. and Borsato, A.: Evoluzione geomorfologica della Bassa Valle dell'Adige dall'Ultimo Massimo Glaciale: sintesi delle conoscenze e riferimenti ad aree limitrofe, Studi Trent. Sci. Nat.-Acta Geol., 82, 31-42, 2005.

Becker, P., Seguinot, J., Jouvet, G., and Funk, M.: Last Glacial Maximum precipitation pattern in the Alps inferred from glacier modelling, Geogr. Helv., 71, 173-187, https://doi.org/10.5194/gh-71173-2016, 2016.

Bigi, G., Castellarin, A., Coli, M., Dal Piaz, G. V., Sartori, R., Scandone, P., and Vai, G. B.: Structural Model of Italy, sheets 1, CNR, S.EL.CA., Firenze, 1990.

Bowen, D. Q.: Last glacial maximum, in: Encyclopedia of Paleoclimatology and Ancient Environments, Springer Netherlands, 493-495, 2009.

Brauer, A., Hajdas, I., Blockley, S. P., Ramsey, C. B., Christl, M., Ivy-Ochs, S., Moseley, G. E., Nowaczyk, N. N., Rasmussen, S. O., Roberts, H. M., Spötl, C., Staff, R. A., and Svensson, A.: The importance of independent chronology in integrating records of past climate change for the 60-8 ka INTIMATE time interval, Quaternary Sci. Rev., 106, 47-66, https://doi.org/10.1016/j.quascirev.2014.07.006, 2014.

Buccianti, A., Pawlowsky-Glahn, V., Barceló-Vidal, C., and Jarauta-Bragulat, E.: Visualization and modeling of natural trends in ternary diagrams: a geochemical case study, in: Proceedings of IAMG'99 - The fifth annual conference of the International Association for Mathematical Geology, edited by: Lippard, S. J., Naess, A., and Sinding-Larsen, R., Trondheim, 139144, 1999.

Burbank, D. W. and Fort, M. B.: Bedrock control on glacial limits: examples from the Ladakh and Zanskar ranges, north-western Himalaya, India, J. Glaciol., 31, 143-149, 1985.

Carraro, A., Fabbri, P., Giaretta, A., Peruzzo, L., Tateo, F., and Tellini, F.: Arsenic anomalies in shallow Venetian Plain (Northeast Italy) groundwater, Environ. Earth Sci., 70, 3067-3084, https://doi.org/10.1007/s12665-013-2367-2, 2013.

Carraro, A., Fabbri, P., Giaretta, A., Peruzzo, L., Tateo, F., and Tellini, F.: Effects of redox conditions on the control of arsenic mobility in shallow alluvial aquifers on the Venetian Plain (Italy), Sci. Total Environ., 532, 581-594, https://doi.org/10.1016/j.scitotenv.2015.06.003, 2015.

Carraro, F. and Sauro, U.: Il Glacialismo "locale" Wurmiano del Massiccio del Grappa (Provincie di Treviso e di Vicenza), Geogr. Fis. Din. Quat., 2, 6-16, 1979.

Carraro, F., Grandesso, P., Sauro, U., and Paoletti, G.: Incontri con il Grappa: i segreti della geologia, Moro Edizioni, 1989.

Carton, A., Bondesan, A., Fontana, A., Meneghel, M., Miola, A., Mozzi, P., Primon, S., and Surian, N.: Geomorphological evolution and sediment transfer in the Piave River system (northeastern Italy) since the Last Glacial Maximum, Géomorphologie, 15, 155-174, https://doi.org/10.4000/geomorphologie.7639, 2009. 
Castellarin, A., Nicolich, R., Fantoni, R., Cantelli, L., Sella, M., and Selli, L.: Structure of the lithosphere beneath the Eastern Alps (southern sector of the TRANSALP transect), Tectonophysics, 414, 259-282, https://doi.org/10.1016/j.tecto.2005.10.013, 2006.

Castiglioni, B.: L'Italia nell'età quaternaria, Atlante Fisicoeconomico d'Italia, Consociazione Turistica Italiana, Milano, Italy, 1940.

Castiglioni, G. B.: Quaternary glaciations in the eastern sector of the Italian Alps, in: Quaternary Glaciations-Extent and Chronology, edited by: Elhers, J. and Gibbard, P., 209-215, https://doi.org/10.1016/S1571-0866(04)80072-1, 2004.

Castiglioni, G. B., Meneghel, M., and Sauro, U.: Elementi per una ricostruzione dell'evoluzione morfotettonica delle Prealpi Venete, Geogr. Fis. Din. Quat., 1, 31-44, 1988.

Clark, P. U., Dyke, A. S., Shakun, J. D., Carlson, A. E., Clark, J., Wohlfarth, B., Mitrovica, J. X., Hostetler, S. W., and McCabe, A. M.: The last glacial maximum, Science, 325, 710-714, https://doi.org/10.1126/science.1172873, 2009.

Colgan, W., Rajaram, H., Abdalati, W., McCutchan, C., Mottram, R., Moussavi, M. S., and Grigsby, S.: Glacier crevasses: Observations, models and mass balance implications, Rev. Geophys., 54, 119-161, https://doi.org/10.1002/2015RG000504, 2016.

Comas, M. and Thió- Henestrosa, S.: CoDaPack 2.0: a stand-alone multi-platform compositional software, in: CoDaWork'11: 4th International Workshop on Compositional Data Analysis, edited by: Egozcue, J. J., Tolosana-Delgado, R., and Ortego, M. I., Saint Feliu de Guixols, Girona, Spain, 2011.

Cucato, M.: Rilevamento della media Val d'Astico (Provincia di Vicenza): saggio per 1 'applicazione della normativa sulla cartografia geologica del Quaternario continentale, B. Serv. Geol. Ital., 99-130, 2001.

Dal Piaz, G., Fabiani, R., Trevisan, L., and Venzo, S.: Carta geologica delle tre Venezie al 100.000, foglio 37-Bassano del Grappa, Ufficio Idrografico Magistrato delle Acque, Venezia, 1946.

Donnici, S., Serandrei-Barbero, R., Bini, C., Bonardi, M., and Lezziero, A.: The caranto paleosol and its role in the early urbanization of Venice, Geoarchaeology, 26, 514-543, 2011.

Egholm, D. L., Knudsen, M. F., Clark, C. D., and Lesemann, J. E.: Modeling the flow of glaciers in steep terrains: The integrated second-order shallow ice approximation (iSOSIA), J. Geophys. Res.-Earth, 116, F02012, https://doi.org/10.1029/2010JF001900, 2011.

Evans, I. S.: Glacier distribution in the Alps: statistical modelling of altitude and aspect, Geogr. Ann. A, 88, 115-133, https://doi.org/10.1111/j.0435-3676.2006.00289.x, 2006.

FAO: World Reference Base for Soil Resources, Food and Agriculture Organization of the United Nations, Rome, Italy, 1998.

Florineth, D. and Schlüchter, C.: Alpine evidence for atmospheric circulation patterns in Europe during the Last Glacial Maximum, Quaternary Res., 54, 295-308, https://doi.org/10.1006/qres.2000.2169, 2000.

Fontana, A., Mozzi, P., and Bondesan, A.: Alluvial megafans in the Venetian-Friulian Plain (north-eastern Italy): Evidence of sedimentary and erosive phases during Late Pleistocene and Holocene, Quaternary Int., 189, 71-90, https://doi.org/10.1016/j.quaint.2007.08.044, 2008.

Fontana, A., Monegato, G., Zavagno, E., Devoto, S., Burla, I., and Cucchi, F.: Evolution of an Alpine fluvioglacial system at the LGM decay: the Cormor megafan (NE Italy), Geomorphology,
204, 136-153, https://doi.org/10.1016/j.geomorph.2013.07.034, 2014.

Garzanti, E., Andò, S., and Vezzoli, G.: The continental crust as a source of sand (southern Alps cross section, northern Italy), J. Geol., 114, 533-554, https://doi.org/10.1086/506159, 2006.

Garzanti, E. Andó, S., France-Lanord, C., Censi, P., Vignola, P., Galy, V., and Lupker, M.: Mineralogical and chemical variability of fluvial sediments 2. Suspended-load silt (GangaBrahmaputra, Bangladesh), Earth Planet. Sc. Lett., 302, 107120, https://doi.org/10.1016/j.epsl.2010.11.043, 2011.

Gazzi, P., Zuffa, G. G., Gandolfi, G., and Paganelli, L.: Provenienza e dispersione litoranea delle sabbie delle spiagge adriatiche fra le foci dell'Isonzo e del Foglia: inquadramento regionale, Mem. Soc. Geol. Ital., 12, 1-37, 1973.

Gulley, J. and Benn, D. I.: Structural control of englacial drainage systems in Himalayan debris-covered glaciers, J. Glaciol., 53, 399-412, 2007.

Harper, J. T., Humphrey, N. F., and Pfeffer, W. T.: Crevasse patterns and the strain-rate tensor: a high-resolution comparison, J. Glaciol., 44, 68-76, https://doi.org/10.3189/S0022143000002367, 1998.

Heiri, O., Koinig, K. A., Spötl, C., Barrett, S., Brauer, A., DrescherSchneider, R., Gaar, D., Ivy-Ochs, S., Kerschner, H., Luetscher, M., Moran, A., Nicolussi, K., Preusser, F., Schmidt, R., Schoeneich, P., Schwörer, C., Sprafke, T., Terhorst, B., and Tinner, W.: Palaeoclimate records $60-8 \mathrm{ka}$ in the Austrian and Swiss Alps and their forelands, Quaternary Sci. Rev., 106, 186-205, https://doi.org/10.1016/j.quascirev.2014.05.021, 2014.

Herman, F., Anderson, B., and Leprince, S.: Mountain glacier velocity variation during a retreat/advance cycle quantified using sub-pixel analysis of ASTER images, J. Glaciol., 57, 197-207, https://doi.org/10.3189/002214311796405942, 2011.

Hughes, P. D. and Gibbard, P. L.: A stratigraphical basis for the Last Glacial Maximum (LGM), Quatern. Int., 383, 174-185, https://doi.org/10.1016/j.quaint.2014.06.006, 2015.

Ingersoll, R. V., Bullard, T. F., Ford, R. L., Grimm, J. P., Pickle, J. D., and Sares, S. W.: The effect of grain size on detrital modes: a test of the Gazzi-Dickinson point-counting method, J. Sediment. Res., 54, 103-116, 1984.

Ivy-Ochs, S.: Glacier variations in the European Alps at the end of the last glaciation, Cuadernos Invest. Geogr., 41, 295-315, https://doi.org/10.18172/cig.2750, 2015.

Ivy-Ochs, S., Kerschner, H., Reuther, A., Preusser, F., Heine, K., Maisch, M., Kubik, P. W., and Schlüchter, C.: Chronology of the last glacial cycle in the European Alps, J. Quaternary Sci., 23, 559-573, https://doi.org/10.1002/jqs.1202, 2008.

Kelly, M. A., Buoncristiani, J. F., and Schlüchter, C.: A reconstruction of the last glacial maximum (LGM) ice-surface geometry in the western Swiss Alps and contiguous Alpine regions in Italy and France, Eclogae Geol. Helv., 97, 57-75, https://doi.org/10.1007/s00015-004-1109-6, 2004.

Koppes, M. N. and Montgomery, D. R.: The relative efficacy of fluvial and glacial erosion over modern to orogenic timescales, Nat. Geosci., 2, 644-647, https://doi.org/10.1038/ngeo616, 2009.

Lardeux, P., Glasser, N. F., Holt, T., Irvine-Fynn, T. D., and Hubbard, B. P.: Area and Elevation Changes of a Debris-Covered Glacier and a Clean-Ice Glacier Between 1952-2013 Using Aerial Images and Structure-from-Motion, AGU Fall Meeting Abstracts, https://doi.org/10.13140/RG.2.1.5059.4329, 2015. 
Luetscher, M., Boch, R., Sodemann, H., Spötl, C., Cheng, H., Edwards, R. L., Frisia, S., Hof, F., and Müller, W.: North Atlantic storm track changes during the Last Glacial Maximum recorded by Alpine speleothems, Nat. Commun., 6, 6344, https://doi.org/10.1038/ncomms7344, 2015.

Massari, F., Grandesso, P., Stefani, C., and Zanferrari, A.: The Oligo-Miocene Molasse of the Veneto-Friuli region, Southern Alps, Giorn. Geol., 48, 235-255, 1986.

Miola, A., Bondesan, A., Corain, L., Favaretto, S., Mozzi, P., Piovan, S., and Sostizzo, I.: Wetlands in the Venetian Po Plain (northeastern Italy) during the Last Glacial Maximum: Interplay between vegetation, hydrology and sedimentary environment, Rev. Palaeobot. Palyno., 141, 53-81, https://doi.org/10.1016/j.revpalbo.2006.03.016, 2006.

Monegato, G., Ravazzi, C., Donegana, M., Pini, R., Calderoni, G., and Wick, L.: Evidence of a two-fold glacial advance during the last glacial maximum in the Tagliamento end moraine system (eastern Alps), Quaternary Res., 68, 284-302, https://doi.org/10.1016/j.yqres.2007.07.002, 2007.

Monegato, G., Stefani, C., and Zattin, M.: From present rivers to old terrigenous sediments: the evolution of the drainage system in the eastern Southern Alps, Terra Nova, 22, 218-226, https://doi.org/10.1111/j.1365-3121.2010.00937.x, 2010.

Monegato, G., Pini, R., Ravazzi, C., Reimer, P. J., and Wick, L.: Correlating Alpine glaciation with Adriatic sea-level changes through lake and alluvial stratigraphy, J. Quaternary Sci., 26, 791-804, https://doi.org/10.1002/jqs.1502, 2011.

Monegato, G., Scardia, G., Hajdas, I., Rizzini, F., and Piccin, A.: The Alpine LGM in the boreal ice-sheets game, Sci. Rep.-UK, 7, 2078, https://doi.org/10.1038/s41598-017-02148-7, 2017.

Mozzi, P., Bini, C., Becattini, R., and Mariotti Lippi, M.: Stratigraphy, palaeopedology and palynology of Late Pleistocene and Holocene deposits in the landward sector of the Lagoon of Venice (Italy), in relation to the "Caranto" level, Il QuaternarioItal, J. Quaternary Sci., 16, 193-210, 2003.

Mozzi, P.: Alluvial plain formation during the Late Quaternary between the southern Alpine margin and the Lagoon of Venice (northern Italy), Geogr. Fis. Din. Quat., 7, 219-230, 2005.

Mozzi, P., Piovan, S., Rossato, S., Cucato, M., Abbà, T., and Fontana, A.: Palaeohydrography and early settlements in Padua (Italy), Il Quaternario-Ital. J. Quaternary Sci., 23, 387-400, 2010.

Mozzi, P., Ferrarese, F., and Fontana, A.: Integrating digital elevation models and stratigraphic data for the reconstruction of the post-LGM unconformity in the Brenta alluvial megafan (NorthEastern Italy), Alp. Mediterr. Quaternary, 26, 41-54, 2013.

Norton, K. P., Abbühl, L. M., and Schlunegger, F.: Glacial conditioning as an erosional driving force in the Central Alps, Geology, 38, 655-658, https://doi.org/10.1130/G31102.1, 2010.

Nye, J. F.: The mechanics of glacier flow, J. Glaciol., 2, 82-93, https://doi.org/10.3189/S0022143000033967, 1952.

Pellegrini, G. B., Albanese, D., Bertoldi, R., and Surian, N.: La deglaciazione alpina nel Vallone Bellunese, Alpi meridionali orientali, Geogr. Fis. Din. Quat., 7, 271-280, 2005.

Penck, A. and Brückner, E.: Die Alpen im Eiszeitalter, Tauchnitz, Leipzig, 1909.

Piovan, S., Mozzi, P., and Zecchin, M.: The interplay between adjacent Adige and Po alluvial systems and deltas in the late Holocene (Northern Italy), Géomorphologie, 18, 427-440, https://doi.org/10.4000/geomorphologie.10034, 2012.
Pini, R., Ravazzi, C., and Donegana, M.: Pollen stratigraphy, vegetation and climate history of the last 215 $\mathrm{ka}$ in the Azzano Decimo core (plain of Friuli, northeastern Italy), Quaternary Sci. Rev., 28, 1268-1290, https://doi.org/10.1016/j.quascirev.2008.12.017, 2009.

Preusser, F., Reitner, J. M., and Schlüchter, C.: Distribution, geometry, age and origin of overdeepened valleys and basins in the Alps and their foreland, Swiss J. Geosci., 103, 407-426, https://doi.org/10.1007/s00015-010-0044-y, 2010.

Preusser, F., Graf, H. R., Keller, O., Krayss, E., and Schlüchter, C.: Quaternary glaciation history of northern Switzerland, E\&G Quaternary Sci. J., 60, 282-305, https://doi.org/10.3285/eg.60.23.06, 2011.

Ramsey, C. B.: Bayesian analysis of radiocarbon dates, Radiocarbon, 51, 337-360, https://doi.org/10.1017/S0033822200033865, 2009.

Ravazzi, C., Badino, F., Marsetti, D., Patera, G., and Reimer, P. J.: Glacial to paraglacial history and forest recovery in the Oglio glacier system (Italian Alps) between 26 and $15 \mathrm{kacalBP}$, Quaternary Sci. Rev., 58, 146-161, https://doi.org/10.1016/j.quascirev.2012.10.017, 2012.

Reimer, P. J., Bard, E., Bayliss, A., Beck, J. W., Blackwell, P. G., Bronk Ramsey, C., Buck, C. E., Cheng, H., Edwards, R. L., Friedrich, M., Grootes, P. M., Guilderson, T. P., Haflidason, H., Hajdas, I., Hatté, C., Heaton, T. J., Hoffmann, D. L., Hogg, A. G., Hughen, K. A., Kaiser, K. F., Kromer, B., Manning, S. W., Niu, M., Reimer, R. W., Richards, D. A., Scott, E. M., Southon, J. R., Staff, R. A., Turney, C. S. M., and van der Plicht, J.: IntCal13 and Marine13 radiocarbon age calibration curves 0-50,000 years cal BP, Radiocarbon, 55, 1869-1887, https://doi.org/10.2458/azu_js_rc.55.16947, 2013.

Rossato, S. and Mozzi, P.: Inferring LGM sedimentary and climatic changes in the southern Eastern Alps foreland through the analysis of a $14 \mathrm{C}$ ages database (Brenta megafan, Italy), Quaternary Sci. Rev., 148, 115-127, https://doi.org/10.1016/j.quascirev.2016.07.013, 2016.

Rossato, S., Monegato, G., Mozzi, P., Cucato, M., Gaudioso, B., and Miola, A.: Late Quaternary glaciations and connections to the piedmont plain in the prealpine environment: the middle and lower Astico Valley (NE Italy), Quaternary Int., 288, 8-24, https://doi.org/10.1016/j.quaint.2012.03.005, 2013.

Russell, A. J., Roberts, M. J., Fay, H., Marren, P. M., Cassidy, N. J., Tweed, F. S., and Harris, T.: Icelandic jökulhlaup impacts: implications for ice-sheet hydrology, sediment transfer and geomorphology, Geomorphology, 75, 33-64, https://doi.org/10.1016/j.geomorph.2005.05.018, 2006.

Sacco, F.: Il Glacialismo veneto, L'Universo, 7, 1-40, 1937.

Samartin, S., Heiri, O., Kaltenrieder, P., Kühl, N., and Tinner, W.: Reconstruction of full glacial environments and summer temperatures from Lago della Costa, a refugial site in Northern Italy, Quaternary Sci. Rev., 143, 107-119, https://doi.org/10.1016/j.quascirev.2016.04.005, 2016.

Schlüchter, C.: The Quaternary glaciations of Switzerland, with special reference to the Northern Alpine Foreland, Quaternary Sci. Rev., 5, 413-419, https://doi.org/10.1016/02773791(86)90206-4, 1986

Secco, A.: Note geologiche sul Bassanese, Stabilimento Tipografico Sante Pozzato, 1883. 
Seguinot, J., Jouvet, G., Huss, M., Funk, M., and Preusser, F.: Modelling last glacial cycle ice dynamics in the Alps, EGU Abstracts, 19, 8982, 2017.

Smiatek, G., Kunstmann, H., Knoche, R., and Marx, A.: Precipitation and temperature statistics in high-resolution regional climate models: Evaluation for the European Alps, J. Geophys. Res.Atmos., 114, D19107, https://doi.org/10.1029/2008JD011353, 2009.

Stefani, C., Fellin, M. G., Zattin, M., Zuffa, G. G., Dalmonte, C., Mancin, N., and Zanferrari, A.: Provenance and paleogeographic evolution in a multi-source foreland: the Cenozoic Venetian-Friulian Basin (NE Italy), J. Sediment. Res., 77, 867887, https://doi.org/10.2110/jsr.2007.083, 2007.

Taramelli, T.: Geologia delle provincie venete, Atti della reale Accademia dei Lincei, 8, 303-541, 1882.

Tessari, F.: Geomorfologia del bacino di Lamon, Val Cismon, Alpi Dolomitiche, Museo Tridentino di Scienze Naturali, 1973.

Torma, C., Giorgi, F., and Coppola, E.: Added value of regional climate modeling over areas characterized by complex terrain Precipitation over the Alps, J. Geophys. Res.-Atmos., 120, 39573972, https://doi.org/10.1002/2014JD022781, 2015.

Trevisan, L.: Il glacialismo quaternario nell'Altipiano dei Sette Comuni (Vicenza), Stabilimento tipografico Villarboito F. e figli, 1939.

van der Veen, C. J.: Fracture propagation as means of rapidly transferring surface meltwater to the base of glaciers, Geophys. Res. Lett., 34, L01501, https://doi.org/10.1029/2006GL028385, 2007. van Husen, D.: Die Ostalpen in den Eiszeiten, Geol. Bundes., 1987. Van Husen, D. and Reitner, J. M.: An Outline of the Quaternary Stratigraphy of Austria, E\&G Quaternary Sci. J., 60, 366-387, https://doi.org/10.3285/eg.60.2-3.09, 2011.
Venzo, S.: Studio geotettonico del Trentino meridionale-orientale tra Borgo Valsugana e il Monte Coppolo, Poligrafico dello Stato, Roma, 86 pp., 1940.

Venzo, S.: I depositi quaternari e del neogene superiore nella bassa valle del Piave da Quero al Montello e del Paleopiave nella valle del Soligo (Treviso), Memorie degli Istituti Mineralogia e Geologia dell'Università di Padova, 30, 1-64, 1977.

Vezzoli, G. and Garzanti, E.: Tracking paleodrainage in Pleistocene foreland basins, J. Geol., 117, 445-454, https://doi.org/10.1086/598946, 2009.

von Eynatten, H., Pawlowsky-Glahn, V., and Egozcue, J. J.: Understanding perturbation on the simplex: A simple method to better visualize and interpret compositional data in ternary diagrams, Math. Geol., 34, 249-257, 2002.

Wei, Y., Tandong, Y., Baiqing, X., and Hang, Z.: Influence of supraglacial debris on summer ablation and mass balance in the 24K Glacier, southeast Tibetan Plateau, Geogr. Ann. A, 92, 353 360, https://doi.org/10.1111/j.1468-0459.2010.00400.x, 2010.

Winkler, S. and Matthews, J. A.: Observations on terminal moraine-ridge formation during recent advances of southern Norwegian glaciers, Geomorphology, 116, 87-106, https://doi.org/10.1016/j.geomorph.2009.10.011, 2010.

Wirsig, C., Zasadni, J., Christl, M., Akçar, N., and IvyOchs, S.: Dating the onset of LGM ice surface lowering in the High Alps, Quaternary Sci. Rev., 143, 37-50, https://doi.org/10.1016/j.quascirev.2016.05.001, 2016.

Young, R. A.: The Rietveld method, Oxford University Press, 298 pp., 1993. 